\title{
Intertextual Agōnes in Archaic Greek Epic: Penelope vs. the Catalogue of Women
}

\author{
Thomas J. Nelson
}

\begin{abstract}
Archaic Greek epic exhibits a pervasive eristic intertextuality, repeatedly positioning its heroes and itself against pre-existing traditions. In this article, I focus on a specific case study from the Odyssey: Homer's agonistic relationship with the Catalogue of Women tradition. Hesiodic-style catalogue poetry has long been recognized as an important intertext for the Nekyia of Odyssey 11, but here I explore a more sustained dialogue across the whole poem. Through an ongoing agōn that sets Odysseus's wife against catalogic women, Homer establishes the pre-eminence of his heroine and-by extension-the supremacy of his own poem.
\end{abstract}

\section{Keywords}

Odyssey - Catalogue of Women - Penelope - competition - intertextuality

\section{Competition in Archaic Greek Epic}

Ancient Greek culture was deeply rooted in competition. Contests dominated many aspects of Archaic Greek life, including war, athletics, and craftmanship; but it is in the poetic sphere where this competitive impulse is felt most strongly. ${ }^{1}$ In the Works and Days, Hesiod famously describes Strife spurring on poets as it does craftsmen and potters (24-26), and he later recounts his own poetic victory at a contest held during the funeral games for Amphidamas $(654-659) .^{2}$ The Homeric poems are less explicit in this regard, but they still

1 Griffith 1990; Ford 2002: 272-293; Collins 2004; Barker 20o9; Gostoli, Fongoni and Biondi 2017; Damon and Pieper 2019. On the competitive world of archaic epic, see Martin 1989; van Wees 1992; Scodel 2008; Allan and Cairns 2011; Bassino, Canevaro, and Graziosi 2017. On Eris in epic: Christensen 2018.

2 Notably, pseudo-Longinus redeploys Hesiod's words on Strife to justify literary aemulatio (On the Sublime 13.4). For the Works and Days itself as a contest song, see Peabody 1975: 268-272. 
feature the bard Thamyris vying to compete against the Muses (Iliad 2.594$600)$ and Telemachus's claim that "audiences celebrate more the song that comes newest to their ears," a self-reflexive comment on Homer's own drive for novelty and success (Odyssey 1.351-352). ${ }^{3}$ The Homeric Hymns, too, exhibit a similarly eristic flavor: the sixth Homeric Hymn (to Aphrodite) ends by ask-

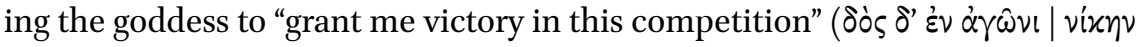

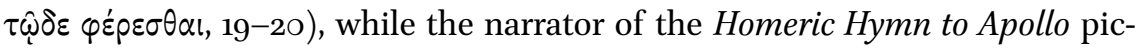
tures the Ionians gathering for a festival "assembly" (or "contest": $\dot{\alpha} \gamma \hat{\omega} v \alpha$ ) with boxing, dancing, and singing (146-150) and shortly thereafter asks the Delian maidens to remember him as the "most pleasurable of poets" whom they "enjoy

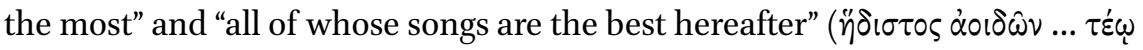

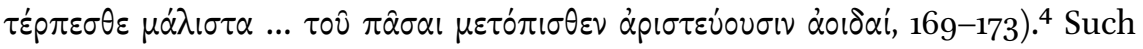
assertions reflect a clear competitive spirit, a drive to be superlative and preeminent. Moreover, the narrator of the first Homeric Hymn to Dionysus begins with a synkrisis of various traditions surrounding the god's birthplace, dismissing them all as false ( $\psi \varepsilon u \delta o ́ \mu \varepsilon v o l, ~ A . ~ 7)$, before settling on his own preferred option, Nysa (A. 1-10), an explicitly agonistic engagement with tradition. Even from this brief survey, we see that archaic epic was produced in an environment highly attuned to its competitive context. ${ }^{5}$

Building on such explicit markers, modern scholars have detected many cases of implicit agonism in archaic Greek epic. They have highlighted, for example, a polemical relationship between the Odyssey and the Iliad, centered especially on the underlying differences between the protagonists of each poem: Odysseus (the man of $\mu \hat{\eta} \tau \iota \varsigma$ ) against Achilles (the figure of $\beta$ in $)$-an attractive, if at times reductive, dichotomy. ${ }^{6}$ And they have explored how both poems compete against a host of other traditions (if not poems), including the Theban war tradition, the exploits of Heracles, and other episodes of the larger Trojan war cycle. ${ }^{7}$ Homeric poetry emerges as "meta-epic," in the words of

3 Thamyris: Maehler 1963: 16-17; Brillante 1992; Wilson 2006. For Telemachus's claim as a selfreflexive comment on the Odyssey, see Danek 1998: 6o; de Jong 2001: 38; Scodel 2002: 53-54. Demodocus's and Odysseus's various tales in Scheria can also be interpreted as a quasi-poetic competition, paralleling the athletic contest of Odyssey 8: Ford 1992: 114-118.

4 The language of the festival contest (146-150) reverberates in the narrator's boast, strengthen-

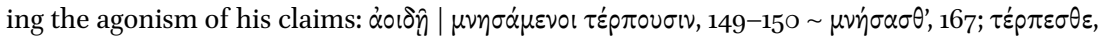
170; ג̇oı $\alpha \dot{l}, 173$.

5 Cf. too our external evidence for the competitive performance of epic in the archaic and classical periods, especially at public festivals: Rotstein 2012; Martin 2015: 17-24; Tsagalis 2018.

6 Nagy 1979: 42-58; Thalmann 1984: 181-183; Edwards 1985; Cook 1995: esp. 28-32; King 1999; Wilson 2005; Currie 2016: 46 with n. 46; Grethlein 2017. Cf. too Lesser 2019 for a comparable rivalry between the Iliadic Helen and Odyssean Penelope (see below).

7 Homer and Theban myth: Barker and Christensen 2020. Iliad and Heracles: Martin 1989: 
Margalit Finkelberg, able to supersede and deauthorize conflicting, alternative versions of myth. ${ }^{8}$ Hesiod, too, has been interpreted within this competitive matrix: in the Theogony, the Muses assert that they can speak "many lies like the truth" (27-28), a claim that has been interpreted as a polemical dig against the falsities of heroic Homeric epic. ${ }^{9}$ In addition, Hesiod's short, brief, and successful voyage from Aulis to Euboea in the Works and Days has been read as a case of agonistic one-upmanship over Homer and the Trojan war tradition, a foil to the long and arduous toils of the Greek expedition (650-653)..$^{10}$ Within the wider context of Hesiod's victory at Amphidamas's funeral games (648662), this final episode likely inspired the tradition of the Certamen Homeri et Hesiodi: already in antiquity, audiences discerned a competitive relationship between these two subgenres of epic. ${ }^{11}$ More generally, scholars have also highlighted how Homer exploits the self-interested and personalized narratives of his characters as a foil to emphasize the authority of his own Muse-inspired work. ${ }^{12}$ In short, the agonistic context of archaic epic has inspired an attractive range of readings, allowing a deeper appreciation of the workings of archaic Greek poetics.

Some scholars, however, have questioned the degree of interpoetic agonism in early Greek epic and have argued that interpretations such as these are out of line with the original performance contexts of archaic poetry and go against the ethos and rhetoric of the ancient poems themselves. Ruth Scodel, in particular, has sounded the most significant note of caution, arguing that the internal evidence of the Homeric texts provides little support for such readings. She argues that Homeric heroes are generally respectful of earlier generations, refraining from challenging or competing with them-part of a larger pattern in both epics of former generations proving greater than those of the present. Heroic glory, she insists, is not a zero-sum contest, allowing the Homeric poems to

227-230. Odyssey and Heracles: Alden 2017: 173-184. Homer and the cycle: Barker and Christensen 2015; Finkelberg 2015; Marks 2017. Generally, cf. Epstein 2020.

"Meta-epic": Finkelberg 1998: 154-155, 2003: 78-79, 2011: 202, 207, 2018: 29-34. Cf. too Homer as "meta-cyclic": Burgess 20o6, 2009: 4, 66, 2012: 170; Tsagalis 2011b: 218-228; Finkelberg 2015. For the deauthorizing of rival epichoric variants, cf. Fredricksmeyer 1997: 494495; Marks 2003; 2008: 96-111; Alwine 2009.

See Kambylis 1965: 63; Puelma 1989: 75; Arrighetti 1996. Contrast Nagy 199o: 45-47; Scodel 2001: 112-121.

Steiner 2005: 350, 2007: 182-186; cf. Nagy 1982: 66; Rosen 199o; Dougherty 2001: 21-25; Graziosi 2002: 169-171.

11 See Bassino 2019: esp. 5-7 on the influence of Works and Days 648-662; cf. Graziosi 2001.

12 Kelly 2008: esp. 198-200, considering these internal characters "a pointed and detailed allusion to his competitors and their methods" (199-200); cf. Kelly 2018. 
position their heroes within a traditional canon that has room for them all. The overall ethos is one of deference to tradition, not dominance. ${ }^{13}$ In addition, Scodel has argued that such agonistic readings misrepresent the competitive context of archaic performance: "the poet's real rival," she suggests, "is the poet against whom he is competing here and now, or the poet from down the road who may be hired in his place."14 On her view, it is misguided to explore epic engagement with woolly, vacuous traditions, detached from specific real world contexts.

These are significant criticisms of a major approach to Homeric studiesand they have not, as far as I am aware, been tackled directly. The issue inevitably engages with larger questions about the development of the Homeric texts and how they come to us in the form they do today. But even without getting drawn into such familiar and irresolvable questions, I feel that Scodel's argumentation can and should be reassessed.

For a start, Scodel does not justify why we should only prioritize the initial hypothesized performance context of bard against bard rather than later receptions of these works. If we imagine these poems as transient one-off performances focused on the present, her emphasis on the poet's real-world rivals makes sense. But this seems a reductive reading of the carefully crafted poems as we have them today, which are clearly invested in their own monumentality and the fame of their characters and stories. Most famously, Helen in Iliad 6 pictures herself and Paris as the subject of song in future generations (6.357$358)$, a self-consciousness that nods to the Iliad's own role in preserving these events, while Odysseus too claims to the Phaeacians that his $x \lambda$ Éoร reaches the heavens - thanks in large part to this very poem which preserves his deeds (Odyssey 9.19-20). Such claims as these are themselves a competitive move, an assertion that these stories and songs will continue to be propagated amid a mass of alternative rival traditions. Moreover, Jonathan Ready has recently highlighted how even oral texts are "capable of outlasting the moment," a process of "entextualization" that he already finds evidenced within the character speeches of the Iliad and the Odyssey (2019: 15-74). These epics are evidently

13 Scodel 2004. For her further discussion of the competitive system of Homeric society, see Scodel 2008. Cf. too Sammons 2019: 59, who suggests that the Little Iliad and the Nostoi use the epigonal figure of Neoptolemus to assert that the epic tradition "was not a closed corpus."

14 Scodel 2012: 5o1; cf. 2004: esp. 17. For similar skepticism, see too Burgess 2006: 165 with n. 43, 2009: 58, 2017: 116, 2019b: 138. Somewhat differently, Ready 2019: 75-97 stresses that "challenging" a source text is only one of various functions open to a mediating performer: they may also "replicate" it (exactly copy it) or "reentextualize" it (retell it in different words). 
invested in their reception beyond the "here and now." And such self-conscious reflection on poetic permanence proved a recurring aspect of the Greek literary tradition, as Henry Spelman has recently reminded us in the case of the Homeric Hymn to Apollo (2018a) and Greek lyric more generally (2018b). Archaic Greek poems were not just ephemeral events but enduring artifacts that envisaged their future fame beyond the present. Poets were aware of this later reception and thus competed not only in a one-off contest with immediate rivals in the present but also against an entire canon of tradition to which they aspired to belong. Within such a broader perspective, an agonistic aspect to archaic epic's engagement with tradition is natural, even expected.

In addition, although Homeric heroes may sometimes refrain from competing directly with past heroes, this is not always the case, and there are in fact instances where they claim or are said to outdo their predecessors. In the Iliad, for example, Sthenelus responds to Agamemnon's rebuke of Diomedes by

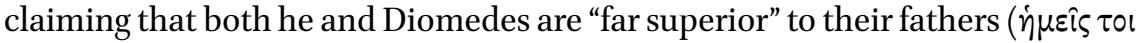

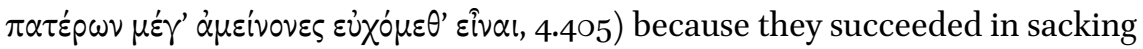
Thebes, even though they faced a greater wall with a smaller force ( $\pi$ avpó-

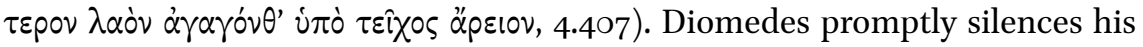
companion's boast, but these remarks invite us to compare and contrast the events at Troy with the great deeds of a former generation at Thebes, hinting at Homer's efforts to surpass this alternative tradition. ${ }^{15}$ In the Odyssey, meanwhile, we could point to Athena's celebration of Odysseus as "by far the best

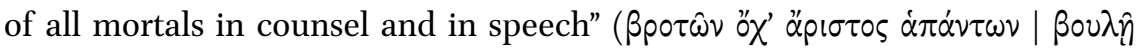
xai $\mu \dot{0} \theta 01 \sigma v, 13.297^{-298)}$ and the dead Agamemnon's synkrisis of Penelope and Clytemnestra in the Underworld, when he explicitly contrasts the fame which Penelope has secured through her fidelity and the hateful song which will remain attached to Clytemnestra's name (24.191-202: see further below). Through these and other such episodes, the Homeric poems set their heroes against the characters of other traditions or poems, hinting at their superiority. There is a sense that the heroic drive to be aristos, to be pre-eminent, does indeed have an intergenerational aspect to it.

In the remainder of this article, I intend to substantiate this point further by exploring one particular case of epic agonism: the Odyssey's relationship with the Catalogue of Women tradition. I aim to highlight an ongoing intertextual rivalry within the Odyssey centered around the figure of Penelope. This rivalry

15 See Sammons 2014; Barker and Christensen 2020: 47-89; Nelson forthcoming a: § IV.2.3. Cf. too Iliad 15.638-652: the Greek warrior Periphetes proves far superior to his father, Copreus, the former herald of Eurystheus. Could Homer be positioning his Trojan narrative here as superior to the Heracles tradition? 
is signposted explicitly near the start of the poem, but it continues to reverberate throughout the whole epic, as the Odyssey poet asserts the superiority of his own poem and heroine. In what follows, I will describe this rivalry primarily in terms of "intertextuality," building on recent studies that have reclaimed this term to describe early Greek epic's interactions with other traditions within an oral framework. ${ }^{16}$ By using this term, I do not mean to suggest that the Odyssey is interacting with a "fixed" poem, a "written text," or even a specific "oral text" (Ready 2019: 15-74). Rather, my focus is on how the Odyssey appropriates and repurposes the characters and themes of a rival oral tradition. This process could equally be framed in terms of "intertraditionality," a more recent coinage (Tsagalis 2014b), but I retain "intertextuality" here to acknowledge the general continuity with the intertextual practices of later generations; even if the target of reference is different ("traditions" rather than "texts"), many of the competitive maneuvers are similar. ${ }^{17}$

\section{The Odyssey versus the Catalogue of Women Tradition}

Scholars have long recognized that the Iliad and the Odyssey presuppose earlier traditions of female catalogue poetry familiar to us from the Hesiodic Catalogue of Women. Margalit Finkelberg has argued that Ajax's appearance in the list of Helen's suitors (fragment 204.44-51 M-W) lies behind his entry in the Homeric catalogue of ships (Iliad 2.557-558), ${ }^{18}$ Lillian Doherty has proposed that the Odyssey and the Catalogue both employ the same story element of the "courtship idyll" (2008); and Ian Rutherford has highlighted various correspondences between the Catalogue of Women and other poems in the early epic tradition. ${ }^{19}$ In particular, Odysseus's catalogue of heroines in the Nekyia (Odyssey 11.225-329) displays considerable overlap with the Hesiodic poem, especially visible in the case of its first heroine, Tyro, and her liaison with Posei-

16 Burgess 2006, 2012; Tsagalis 2008, 2011a, 2011b; Edmunds 2016. For earlier applications of "intertextuality" in Homeric studies, see Pucci 1987; Cook 1995.

17 As Barker and Christensen rightly note, "Homerists will frequently refer to the same phenomena with different language" (2020: 18). In this case, I suspect that my arguments and conclusions are compatible with most methodological and terminological frameworks. For a fuller discussion of my approach to early Greek intertextuality, see Nelson forthcoming a: $§$ I.2.

18 Finkelberg 1988. Though note the caution of Cingano (1990; 2005: 143-151), who sees both texts drawing on epic traditions of heroes and bridal contests and considers the Hesiodic Catalogue an expansion of the abridged Iliadic text.

19 Rutherford 2000: 93-96, 2012. Cf. too Zutt 1894: 13-23; Gazis 2018: 125-156. 
don (11.235-259): the preserved words of several Hesiodic lines precisely parallel Odysseus's own account of the episode, ${ }^{20}$ while the Odyssey's comparison of surging water to a mountain as Poseidon conceals their lovemaking is also said to have occurred in the Catalogue (11.243-244, cf. Hesiod fragment $32 \mathrm{M}-$ W) ${ }^{21}$ Despite the fragmentary state of the Hesiodic poem, there is a clear and strikingly close connection between these two passages.

What we make of these parallels depends in part on our theoretical preconceptions, but I am inclined to accept Rutherford's conclusion that the Catalogue narrative likely predated the Odyssey, even if the Catalogue as we have it is of a later date-a similar conclusion to that regularly drawn concerning the Epic Cycle. ${ }^{22}$ In that case, the surviving fragments of the Catalogue offer potential evidence for the kind of pre-Homeric traditions with which the Odyssey may have engaged. Of course, we must handle this evidence with considerable care and caution, since parts of the Catalogue as we have it may display some Homeric influence, ${ }^{23}$ but even so, our surviving fragments still provide the best window onto the possible contours of lost pre-Homeric traditions. In the immediate context of Odyssey 11, I thus consider it plausible that Homer is evoking earlier female catalogue traditions that would later coalesce into our Hesiodic Catalogue of Women. ${ }^{24}$ As in later literature, so already in the Odyssey, the Underworld is a natural site for direct engagement with the poetic past. ${ }^{25}$

However, this moment is not in fact the first time that the Odyssey engages with female catalogic tradition. The intertextual relationship is already signaled far earlier - and in a far more overtly agonistic manner — during the Ithacan assembly of book 2. Antinous, in his frustration at Penelope's devious tricks

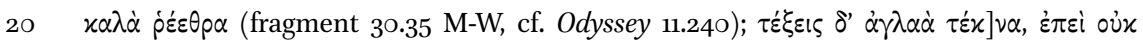

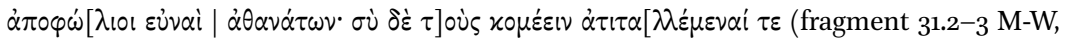
cf. Odyssey 11.249-250). Cf. too the presence of Chloris and her children to Neleus in both poems (esp. fragment $33 \mathrm{a} .12 \mathrm{M}-\mathrm{W}=$ Odyssey 11.286).

21 Note also the line following Poseidon's speech (Odyssey 11.253), which resembles fragment 31.6 M-W.

22 Rutherford 2000: 93-96; 2012: esp. 163. Cf. West 1985: 164-171: most genealogies in our Catalogue were "constructed not later than the eighth century." On the Epic Cycle as both a source for pre-Homeric myth and an assemblage of post-Homeric receptions, see Burgess 2001; 2019a: 18-26.

23 See Ormand 2014: esp. 119-151 (Atalanta and Achilles; contrast Laser 1952), 152-180 (Amphitryon and Odysseus).

24 Thus Rutherford 2012: 161-164. On the Nekyia more generally as a literary-historical catalogue of the subspecies of epos, see Most 1992.

25 Cf. Aristophanes Frogs; Gerytades (fragments 156-19o Kassel-Austin); Callimachus Iambus 1 (fragment 191 Pfeiffer). See Currie 2016: 26-27n166. For Roman and later continuations of this tradition, see Hardie 2004; Deremetz 2005; Parkes 2010. 
for delaying the suitors' advances, claims that she is unrivalled, even among women of a former age (Odyssey 2.115-122):

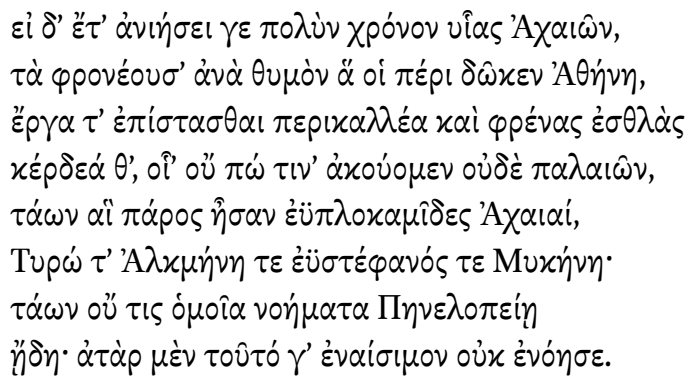

But if she will continue to vex the sons of the Achaeans for a long time, mindful in her heart of the things which Athena has granted her above other women: knowledge of very beautiful handiwork, good sense, and cunning, such as we have never yet heard that any of the women of old knew, those lovely-haired Achaean women who lived long ago: Tyro, Alcmene and Mycene of the lovely garland - not one of them had thoughts similar to Penelope. But this at any rate she has devised improperly. ${ }^{26}$

Antinous here compares Penelope with three women of the distant past: Tyro, Alcmene, and Mycene, all of whom occupy prominent positions in Greek myth as the ancestors of many of its most famous heroes. In giving birth to Pelias, Neleus, Aeson, Pheres, and Amythaon (Odyssey 11.254-259), Tyro in particular counts numerous heroes from the Trojan, Theban, and Argonautic sagas in her lineage, including Admetus, Adrastus, Jason, Melampus, and Nestor; Alcmene was the mother of Heracles, whose numerous affairs ensured a plentiful progeny; and Mycene (the eponymous heroine of Mycenae) was a significant ancestor in the Argive family tree as the mother of Argus, guardian of Io. By claiming that Penelope surpasses such eminent figures of the distant past, Antinous aims to criticize her unconventional "cunning" ( $\chi \varepsilon \dot{\varepsilon} \delta \varepsilon \varepsilon \alpha, 118$ ), a trait that he has already blamed for the current impasse on Ithaca (cf. 2.88). ${ }^{27}$ But in

$26 \quad$ All translations are my own.

27 This unconventionality is reflected in Homer's language: Odyssey 2.117 seems to be a formulaic verse celebrating traditional female virtues (it reappears at Odyssey 7.111 of the Phaeacian women), but the enjambed $\chi \varepsilon ́ p \delta \varepsilon \alpha$ are a unique addition: Katz 1991: 4; Sammons 2010: 6o-61. On Penelope's intelligence in general, see Marquardt 1985; Murnaghan 1986. 
so doing, he inadvertently praises Penelope's exceptionality and highlights her obvious appeal: on the basis of this comparison, whoever succeeds in wooing her will enjoy an illustrious and unsurpassed progeny — though as Georg Danek notes, this comparison also exposes the suitors' hubris: all three of these mythical women had divine lovers, so if Penelope surpasses them, she is completely out of the suitors' league (1998: 74$){ }^{28}$

Besides this ironic reflection on the suitors' situation, Antinous's direct contrast between Penelope and these other mythical women also activates a more allusive contrast between the Odyssey and female genealogical poetry. All three of Antinous's comparanda feature prominently in Hesiodic catalogue poetry: we have already encountered Tyro's presence in both the Hesiodic Catalogue and the Odyssean Nekyia (Odyssey 11.235-259; Hesiod fragments 30-32 M-W), while we can find Alcmene in both lists (Odyssey 11.266-268; Hesiod fragment 193.19-20, fragment 195.8-63 M-W = Scutum 1-56), as well as in the Great Ehoiai (fragments 248-249 M-W), where Mycene is also said to have featured (fragment $246 \mathrm{M}-\mathrm{W}) .{ }^{29}$ Given the close combination of these women here, Antinous's words point towards pre-existing female catalogue traditions, just as Odysseus's do in the Nekyia. The likelihood of a reference to such traditions is further reinforced by the very nature of these lines: by listing the women in a miniature catalogue, Antinous repeats the compositional technique of Ehoiai poetry itself, while the word with which he introduces them, the relative pronoun oi $\alpha$ (2.118), acts as a generic signpost, echoing the common introductory formula of such poetry (ï oin). ${ }^{30}$ Antinous's comparison imitates the key features of Hesiodic catalogue poetry at the same time as he evokes some of its principal protagonists. ${ }^{31}$

The allusive nature of these verses is sealed, however, by their carefully marked framing: Antinous introduces these women by stressing their antiquity

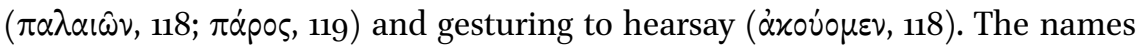
of these women have reached him through transmitted tales, while their age

28 The irony is even stronger when we recall that Tyro was famous for warning her father not

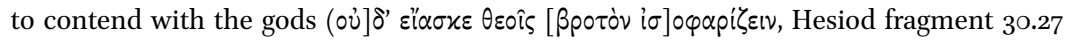
$\mathrm{M}-\mathrm{W})$; Antinous too should heed this advice.

29 On the Great Ehoiai and its relationship to the Ehoiai: Hirschberger 2004: 81-86; D'Alessio 2005 .

$30 \quad$ Skempis and Ziogas 20og: 234. The listing of three names in a single verse in Odyssey 2.120 (an "augmented triad": West 2004) is also typical of hexameter catalogues: cf. Hesiod Theogony 338-345; fragment 33a.9-12 M-W; West 2007: 117-119.

31 Compare also ov̈ $\pi \omega^{\prime} \tau \iota \nu^{\prime}$ (Odyssey 2.118) ov้ $\pi \omega^{\prime} \tau \iota \varsigma$ (Hesiod fragment 195.17 M-W, see below), a parallel that further highlights the degree to which Alcinous appropriates the rhetoric of female catalogue poetry. 
marks the venerability of these traditions and heightens the contrast with the present. Stephanie West remarks that "the antiquarian note" of these lines "is slightly strange" (1988: 139), but I suggest that these elements function here as intertextual markers, precursors of the "Alexandrian footnote."32 Roman poets frequently present details familiar from other texts as the product of fama ("rumor") and refer to traditional characters as antiquus ("ancient") self-conscious gestures that are usually considered the preserve of Hellenistic and later poets. ${ }^{33}$ Yet already here, Antinous's appeal to hearsay and his assertion of these women's antiquity seem to act in a similar manner, signposting allusive engagement with catalogic tradition. ${ }^{34}$ After all, as regular "auditors"

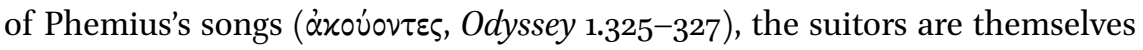
"aficionados of epic poetry" (Sammons 2010: 61n8); it is no surprise if Antinous derives his knowledge from older song traditions.

Given this evocation of Hesiodic catalogue poetry, Antinous's comparison thus does much more than simply highlight Penelope's desirability and objectionable craftiness. It also sets her Odyssean self against representatives of another rival poetic tradition, a significant agonistic move. Despite Antinous's attempts to criticize her $\chi \varepsilon ́ p \delta \varepsilon \alpha$, this comparison is in fact very favorable when viewed against the poem's broader ideological framework. Penelope's exceptional $\chi \varepsilon \dot{\rho} \delta \varepsilon \alpha$ make her a prime match for Odysseus, whose own unmatched

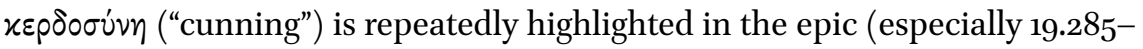
286; cf. 4.251, 13.297, 14.31; Iliad 23.709). In addition, the only other specific figures whose $\chi \varepsilon$ é $\delta \varepsilon \alpha$ are mentioned in the Odyssey are the couple's son, Telemachus (18.216, 20.257), and Odysseus's divine patron, Athena (13.297, 299). Within the broader context of the poem, $\chi \varepsilon \dot{p} \delta \varepsilon \alpha$ are valorized as the emblematic and unifying trait of Odysseus's household: $x \varepsilon \dot{p} \rho \delta \varepsilon \alpha$ are "arguably a defining theme of the Odyssey itself" (Sammons 2010: 61). ${ }^{35}$ By having Antinous assert

32 On the Alexandrian footnote, see Hinds 1998: 1-3; cf. Wills 1996: 30-31 ("external markers of allusion").

33 Fama: for example, Ovid Metamorphoses 12.197 (ita fama ferebat, "so rumor had it"), 12.200 (eadem hoc quoque fama ferebat, "the same rumor reported this too"), looking to the Hesiodic Catalogue's account of Neptune's rape of Caenis (Ziogas 2013:198-199). Antiquus: for example, Aeneid 12.347 (antiqui ... Doloni, "of old Dolon"), looking back to Iliad 10 (cf. too quondam, 12.349; Tarrant 2012: 177).

34 This is not the only plausible instance of such allusive devices in Homer: see, for example,

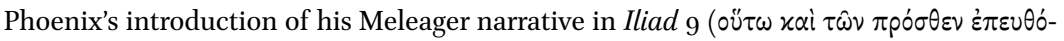

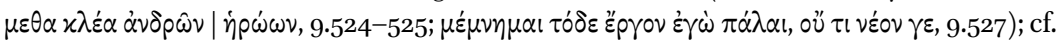
Currie 2016: 140-143; Rawles 2018: 43 with n. 6o; Nelson forthcoming a, forthcoming b.

35 Notably, this positive Odyssean assessment of $\chi \dot{\varepsilon} \rho \delta \varepsilon \alpha$ contrasts with a largely critical evaluation elsewhere in early Greek epic: for example, Hesiod's warning about the dangerous

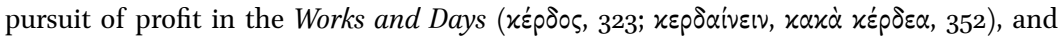


Penelope's superiority to catalogic women in these terms, Homer thus agonistically hints at the superiority of the tale in which she features: just as Penelope surpasses these women of the past, so too does the Odyssey trump the Hesiodic tradition of female catalogues. ${ }^{36}$ Antinous's ensuing claim seals this agonistic one-upmanship: Penelope is winning great $x \lambda$ Éos for herself-not just a "noto-

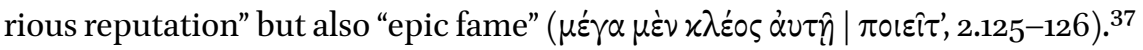
As she surpasses the likes of Tyro and Alcmene, she too joins the ranks of those who are the subject of song in their own right.

The polemic of this comparison is heightened further when we consider how these Hesiodic women were themselves presented as unrivalled paragons of womanhood. The Hesiodic Catalogue explicitly sets out to list those women who were "the best at that time [and the most beautiful on earth]" (ai $\tau$ ó $\tau$ '

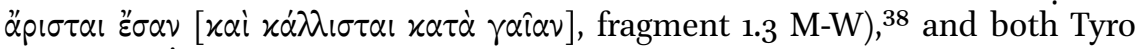
and Alcmene are further celebrated as flawless models of femininity in their own entries in the Catalogue: Tyro surpasses all female women in beauty ( $\varepsilon \hat{\delta} \delta \circ \varsigma$

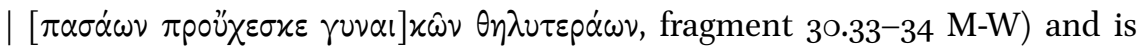

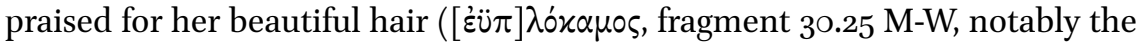
same epithet that Antinous uses of the Achaean women of the past: $\varepsilon \ddot{v} \pi \lambda \circ \alpha \alpha-$ $\mu i ̂ \delta \varepsilon \varsigma$ 'A $\chi \alpha \iota \alpha$ ', Odyssey 2.119). Alcmene, meanwhile, receives a particularly lavish encomium (Hesiod fragment 195.11-17 M-W = Scutum 4-10):

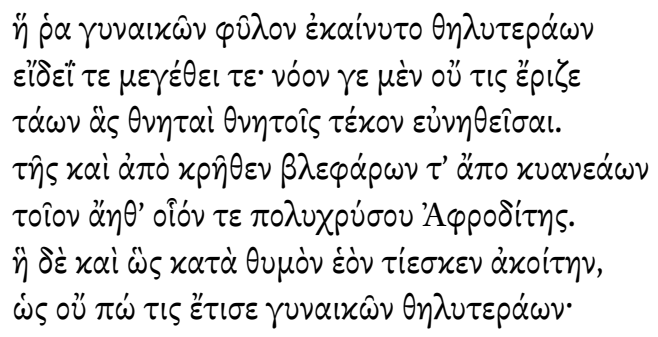

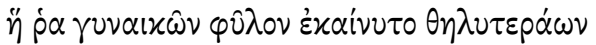

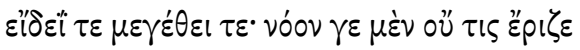

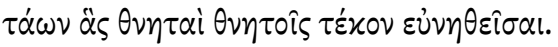

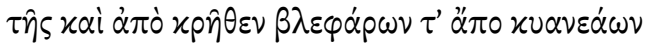

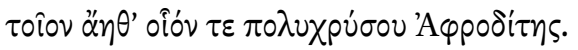

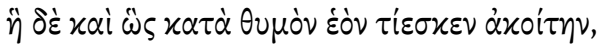

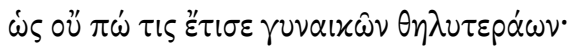

Antilochus's reckless behavior in the chariot race of Iliad 23 (

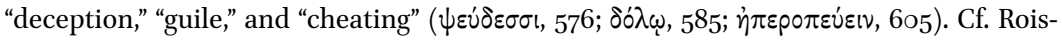
man 1994; Dougherty 2001: 38-6o; Tsagalis 2009: 152-154.

36 Cf. Sammons 2010: 6o-62, suggesting that "Penelope's unprecedented cleverness" allows Homer to sustain a plot devoted to a single tale (as Aristotle admired), in comparison to the more episodic catalogic tradition.

37 Thus Sammons 2010: 61; cf. Clayton 2004: 34. For the association of $x \lambda$ źos and song, see Nagy 1974: 246-252.

38 Merkelbach's proposed supplements here and in fragment 30.34 reinforce my argument. But even if we leave the lacunae unsupplemented, these verses still display an emphasis

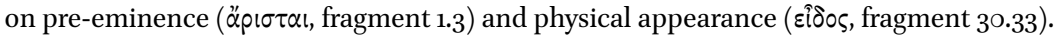


She surpassed the tribe of female women in beauty and stature; and as for her mind, no woman could rival her, out of all those whom mortal women bore after sleeping with mortal men. Such charm wafted from her head and dark eyelids as comes from golden Aphrodite. And she honored her husband in her heart as no other female woman has ever yet honored hers.

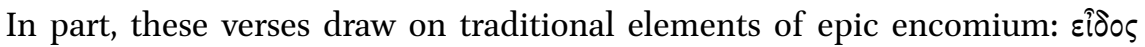
and $\mu \varepsilon \gamma \varepsilon \theta \circ$ are frequently combined in the praise, criticism, or description of an individual's physique, alongside other nouns such as $\delta \dot{\varepsilon} \mu \alpha \varsigma$ and $\varphi v \eta^{\prime}{ }^{39}$ The image of wafting beauty is paralleled elsewhere in the Catalogue (fragment 43a.73-74 M-W) and the Homeric Hymn to Demeter (276). Yet the larger focus here on Alcmene's vóos and marital fidelity are uncommon in such descriptions: $\varphi$ péves are sometimes picked out for comment, ${ }^{40}$ and yet the only other mention of vóos in such contexts is Odysseus's negative dismissal, during the Phaeacian games of Odyssey 8, of Euryalus's "stunted mind" in comparison

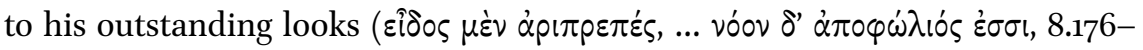
177). The Hesiodic poet's emphasis on this attribute here in pointedly com-

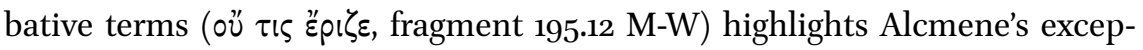
tionality. So too does the "honor" which she pays to her husband (fragment 195.16-17 M-W), an expression that finds no direct parallel in the early Greek tradition, ${ }^{41}$ although there is perhaps an underlying touch of irony given her coming "affair" with Zeus during Amphitryon's absence. ${ }^{42}$ In any case, if these two traits (intelligence and fidelity) were particularly associated with Alcmene in early genealogical traditions, as the uniqueness of these lines may suggest, Antinous's use of her in the Odyssey as a foil to Penelope has even more point. Not only does Penelope surpass the best women of the past but she eclipses even her closest rival in wit and marital loyalty. ${ }^{43}$ She remains faithful to her

39 Iliad 2.58; Odyssey 5.217, 6.152, 14.177, 24.253, 24.374; Homeric Hymn to Demeter 275; Homeric Hymn to Aphrodite 85. Cf. Iliad 23.66-67, where tradition is adapted to describe Patroclus's

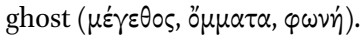

$40 \quad$ Iliad 1.115; Odyssey 4.264, 11.337, 14.178, 17.454, 18.249.

41 The only close parallel is the honor Alcinous shows to his wife, Arete, in Scheria (Odyssey 7.66-70), although here the genders are reversed.

42 Hesiod fragment 195.34-63 M-W = Scutum 27-56; cf. Diodorus Siculus 4.9; Apollodorus Bibliotheca 2.4.8. An erotic context is evoked by the comparison to Aphrodite (fragment 195.15 M-W) and the mention of Alcmene's "dark eyelids" ( $\beta \lambda \varepsilon \varphi \alpha \dot{\rho} \omega \nu \nu . . . \chi v \alpha v \varepsilon \alpha \dot{\alpha} \omega \nu$, fragment

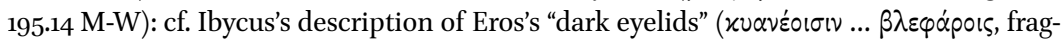
ment 287.1-2 Davies).

This direct rivalry may even be asserted on a verbal level: note the similar phrasing of $\tau \dot{\alpha} \omega \nu$ 


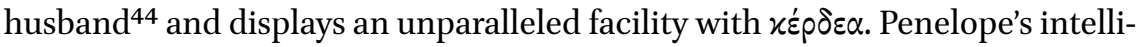
gence is unsurpassed, which makes her the perfect match for Odysseus andironically - completely unsuitable for Antinous, whose very name betrays his hostility to sensible thought ( $\dot{\alpha} v \tau \dot{\imath}+$ vóos: "enemy of discernment"). ${ }^{45}$

Antinous's words in Odyssey 2 thus position Penelope against key representatives of female catalogue poetry. Penelope proves superior even to the most intelligent and loyal women of this rival poetic tradition, a pre-eminence which reflects positively on the Homeric poet himself: his subject matter surpasses that of his predecessors. Near the start of the whole epic, Homer asserts the preeminence of his female protagonist and his own poetry, and he does so-rather ironically - through the ambivalent voice of a suitor. Although Antinous may attempt to criticize Penelope's cunning, his synkrisis in fact foregrounds her exceptionality and unwittingly proves how suitable she is not only as a match for Odysseus but also as an emblem for the poem itself.

\section{Reverberations: The Agōn Continues}

This assertion of Penelope's superiority is not a one-off passing reference. Antinous's words resonate and echo throughout the Odyssey with a similarly agonistic point. At key moments in the narrative, Penelope is praised for the same traits and in the same manner-through comparison with the women of the Catalogue. Antinous's inadvertent praise inaugurates an ongoing agōn that pervades the poem.

We have already mentioned the catalogue of heroines in the Odyssean Nekyia (11.225-329). ${ }^{46}$ Scholarship traditionally emphasizes how this catalogue is tailored to one particular member of Odysseus's immediate internal audience, queen Arete. ${ }^{47}$ But for Homer's external audience, the catalogue also

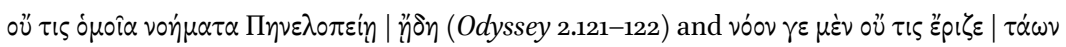
(fragment 195.12-13 M-W).

44 Cf. Winkler 1990: 151: Penelope's "superiority lies precisely in her unwillingness to be taken in by what might be merely a convincing replica, whether mortal or immortal, of her husband" (Poseidon disguises himself as Tyro's beloved, Enipeus, and Zeus as Alcmene's husband, Amphitryon). On Penelope's fidelity, cf. Foley 1995: esp. 103; Zeitlin 1995; Lesser 2017.

45 For this etymology, cf. Peradotto 1990: 107; Kanavou 2015: 132. The anacoluthon in Antinous's speech exemplifies his lack of vóos: after the $\varepsilon i$ of 2.115 , we are left waiting for an apodosis that never arrives.

46 On this catalogue in general, see Pade 1983; Houlihan 1994; Steinrück 1994; Hirschberger 2001; Sammons 2010: 74-93; Larson 2014.

47 Büchner 1937:107; Heubeck 1954: 33; Stanford 1959: 381; Wyatt 1989: 240; Doherty 1991, 1992: 
establishes these women as comparanda for Penelope. Not only does it follow immediately after Odysseus's conversation with his mother, Anticleia, in which he hears of Penelope's enduring heart (11.181-183). It also begins by overlapping significantly with Antinous's previous catalogue: Tyro appears first in both lists (2.120, 11.235-259), while Alcmene also features prominently in each (in second and third place respectively: 2.120, 11.266-268). By frontloading this Underworld catalogue with two of the women whom Antinous had already compared to Penelope, Homer invites us to position all the others that follow against Odysseus's wife. Many are seduced and raped by a disguised god, especially Zeus (Alcmene, Antiope, Leda, Maera) and Poseidon (Iphimedeia, Tyro); others are killed or abandoned by their male partner (Megara, Procris, Ariadne); while others still remarry (Clymene), betray their husband (Eriphyle), or are possessed by an unnatural desire for their (step-)son (Epicaste, Phaedra). ${ }^{48}$ Their unhappy loves and their various affairs stand in stark contrast to Penelope's enduring fidelity. ${ }^{49}$ The majority, moreover, also feature in our extant Hesiodic fragments, and most of the rest likely featured in sections of the Catalogue that no longer survive. ${ }^{50}$ Here too, Homer introduces representatives of catalogic tradition as a foil for Penelope. As elsewhere in Odysseus's Apologos, we are encouraged to look back (and ahead) to the situation on Ithaca.

This synkrisis with catalogic women is made even clearer in the second Nekyia at the end of the Odyssey, when Agamemnon talks to the dead suitor Amphimedon and explicitly compares Penelope and Clytemnestra, an episode that we have already noted in passing (24.191-202):51

168-169, 1995: 87-126; Tsagarakis 200o: 83; West 2012: 130; Barker and Christensen 2020: 153n77. Athena had encouraged Odysseus to win Arete's favor (Odyssey 7.75-77) and she is the first to respond when he finishes the catalogue (Odyssey 11.335-341).

48 For the stories of Maera and Procris, see Pherecydes fragment 170 and fragment 34 EGM respectively. The former was raped by Zeus and gave birth to Locrus, a companion of Amphion and Zethus; the latter failed her husband Cephalus's test of her fidelity and was later killed by him in a hunting accident, although West suggests that this is a fifth-century Attic tradition and that in the Catalogue she might have also been "the object of a god's desire" (1985: 106-107).

49 See esp. Alden 2017: 47-54, 103-112. Cf. too Walcot 1959; Northrup 1980; Danek 1998: 231; Barker and Christensen 2020:131-171. Notably, four of the same women feature in Nestor's catalogue of problematic women in the Cypria (argumentum $4 \mathrm{~b}$ GEF: Antiope, Epicaste, Megara, Ariadne): Sammons 2010: 91; Alden 2017: 48-49, 105-107, 110.

50 Thus Rutherford 2000: 93. Those who do not appear in our extant fragments all appear elsewhere in early Greek epic: see Appendix.

51 The authenticity of our ending of the Odyssey has been questioned in the past, but I regard it as an integral part of the poem's larger unity: cf. Moulton 1974; Wender 1978; Erbse 1972: 166-244; Kelly 2007: $384-387$. 


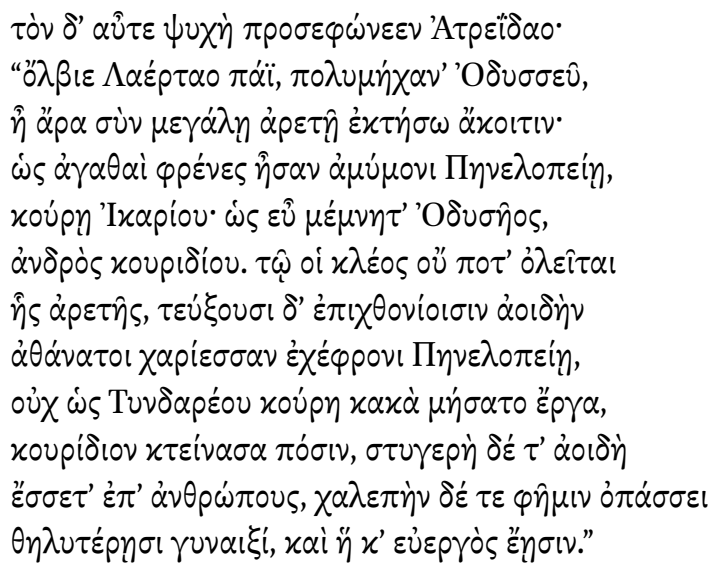

Then the soul of Atreus's son answered him: "Blessed son of Laertes, Odysseus of many wiles, you truly obtained a wife of great virtue. How good of understanding was excellent Penelope, daughter of Icarius! How well did she retain the memory of Odysseus, her wedded husband! And so the fame of her virtue will never die, and the immortals will fashion a delightful song for those on earth in honor of prudent Penelope. Not so the daughter of Tyndareus, who plotted evil deeds and killed her wedded husband. Her song will be hateful among mankind, and she will bestow a dire reputation on the whole female sex, even on her who acts rightly."

Agamemnon's ghost praises Penelope's "great virtue" ( $\mu \varepsilon \gamma \alpha \dot{\lambda} \lambda \eta \dot{\alpha} \rho \varepsilon \tau \hat{n}, 24.193$, cf.

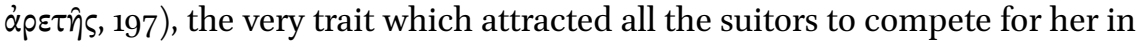
the first place (2.205-207), and he celebrates her in the same terms as Antinous

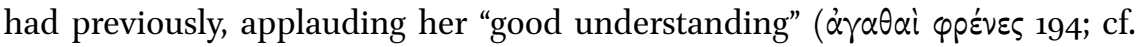

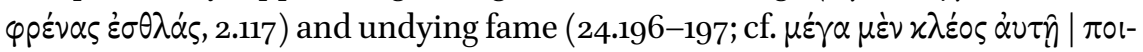
$\varepsilon \hat{\imath} \tau^{\prime}, 2.125^{-126)}$. As in book 2, this Penelopean praise can be read metapoetically, reflecting the Odyssey's bid for poetic supremacy (Tsagalis 2008: 30-43), and here too it is secured through comparison with another woman of the mythical past: in this case, Agamemnon's own wife, Clytemnestra. It is well known that the Odyssey repeatedly engages with a well-established "Oresteia" tradition, establishing Agamemnon, Clytemnestra, and Orestes as parallels and foils for Odysseus, Penelope, and Telemachus. ${ }^{52}$ It is less commonly acknowledged, however, that this story also featured in the Hesiodic Catalogue (fragment

52 See D’Arms and Hulley 1946; Hölscher 1967; Olson 1990, 1995: 24-42; Katz 1991: 29-53; Felson 1994: 93-107; Marks 2008: 17-35; Tsitsibakou-Vasalos 2009; Alden 2017: 77-100. 
23a.27-30 M-W). Just like Tyro, Alcmene, and Mycene, Clytemnestra stands as a representative of this rival tradition, who again proves inferior to Penelope. In this regard, it is worth noting a significant verbal overlap between the Odyssey and the Hesiodic Catalogue: in both poems, Orestes is said to have "killed" or

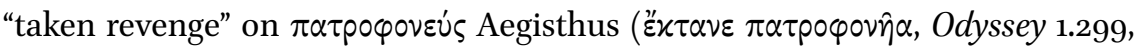

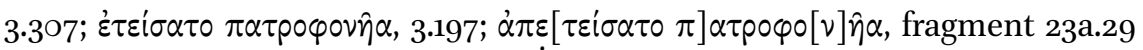
$\mathrm{M}-\mathrm{W}$ ). These are the only four instances of $\pi \alpha \tau$ po ovevé ( "father-murderer") in extant Greek poetry, all in the same metrical sedes. The Odyssey's abbreviated accounts of the "Oresteia" story may thus look in part to a specifically catalogic telling of the tale. In one of the poem's final mentions of Penelope, Odysseus's wife is here once more positioned against another woman of the catalogue tradition.

Such catalogic agonism also reverberates elsewhere in the Odyssey when characters assert Penelope's superiority even without an explicit comparison to other named women. When Penelope speaks to the disguised Odysseus on his return to Ithaca, for example, she wants him to learn whether she is "preeminent among other women" for her "intelligence and prudent cunning," themat-

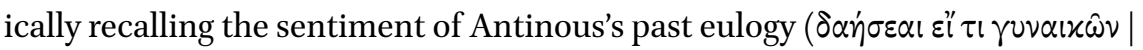

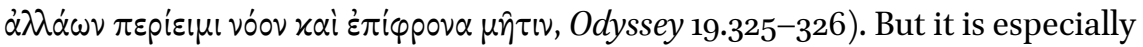
Telemachus's compliments before the bow contest in Odyssey 21 that resonate with Antinous's earlier words (21.106-110):

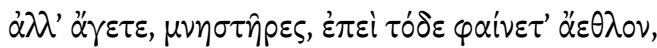

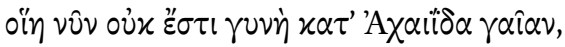

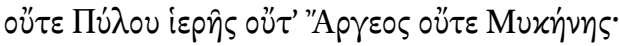

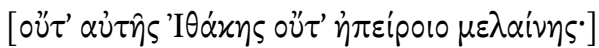

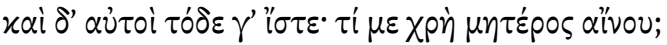

But come now, you suitors, since this here is your prize before you: there is no other woman like her today throughout the Achaean land, neither in holy Pylos, nor in Argos, nor in Mycenae. [Nor in Ithaca itself, nor on the dark mainland.] But you know this yourselves; what need have I to praise my mother?

Like Antinous's former praise, these verses evoke key features of the Hesiodic catalogue tradition: the oin (21.107) nods to the formula of female catalogue poetry, like oi $\alpha$ in book $2,{ }^{53}$ while the very context of these lines-the woo- 
ing of a woman and the idea of a woman as a prize ( $\left.\alpha^{\prime} \varepsilon \theta \lambda \circ v\right)$-resonates with many of the common themes of the catalogic genre. ${ }^{54}$ Here too, Penelope is set against the traditions of the Catalogue and comes out on top. Yet these lines also have a closer connection with Antinous's earlier words than has been observed before. The initial trio of cities which Telemachus lists are all intimately linked with Antinous's own exempla: Tyro's descendants ruled Pylos (Neleus/Nestor); Alcmene was from Argos, while her son Heracles was frequently imagined as the ruler of the locality (cf. Iliad 15.29-30); and the city of Mycenae drew its name from Mycene herself. ${ }^{55}$ Telemachus's words thus not only evoke traditions of female catalogue poetry but also map directly onto Antinous's list of three women, recalling the agonistic intertextuality of that earlier episode. After all, Telemachus ends by claiming that the suitors themselves "know"

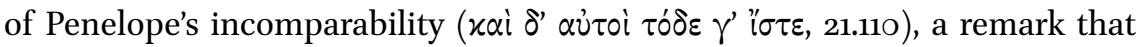
acknowledges their (and the external audience's) familiarity with Antinous's earlier words. ${ }^{56}$ On the threshold of the Mnesterophonia, Homer's audience are pointed back to the start of the poem and to Antinous's initial encomium of Penelope. At this climactic point of the narrative, we are reminded that Penelope is completely out of the suitors' league; their impending deaths will be no surprise.

The initially signposted contrast with another literary tradition and its paradigmatic representatives thus continues to resonate through the whole poem. Both explicitly and implicitly, Penelope is presented as a foil for the women of the Catalogue. She surpasses them in her loyal fidelity and in her intelligence and cunning — a key trait that aligns her not only with Odysseus but also with the poet of the Odyssey. ${ }^{57}$ Indeed, this conclusion complements Rachel Lesser's recent argument that the Odyssey positions itself against the Iliad through a direct comparison of Penelope and Helen, each character embodying the ethics and ideology of their respective epic (2019). In a similar way, we have seen here that Penelope lies at the center of another intertextual rivalry:

54 Cf. Skempis and Ziogas 2oog: 234n59, whose examples include Atalanta (fragments 72-76 $\mathrm{M}-\mathrm{W}$ ), Mestra (fragment 43a.21 M-W), and Helen (fragments 196-204 M-W).

55 This interpretation may lend additional support to the deletion of Odyssey 21.109, which introduces Ithaca and the mainland, places which are unnecessary for the allusive backreference. The line appears to be a "concordance interpolation": it is absent in many manuscripts, seems to have been adapted from Odyssey 14.97-98, and is "out of place" after the mention of "the Achaean land" in 107 (Fernández-Galiano 1992: 158 on 21.107).

$5^{6}$ For the language of knowledge as a marker of intertextuality, see Nelson forthcoming a: $\S$ III.

57 Penelope and Odysseus: Foley 1978. Penelope and Homer: Winkler 199o: 129-161 ("Penelope's Cunning and Homer's"). 
by repeatedly setting her against the myriad women of the Catalogue, Homer establishes her-and his own-pre-eminence.

However, there might be more at stake in this intertextual maneuver than a simple assertion of poetic superiority: Homer's insistence on Penelope's excellence may also be a polemical move in itself. We know from various later sources that Penelope was not in fact always as faithful as she appears in our Odyssey. Already in Herodotus, we hear that Penelope bore Pan to Hermes (2.145.4), a detail that is repeated by numerous later writers and seems to go back at least as far as Pindar (fragment 100 Snell-Maehler). ${ }^{58}$ Duris of Samos offers an even more ignoble version of this story, in which Penelope bore the "goat-legged" god ( $\tau p \alpha \gamma \circ \sigma x \varepsilon \lambda \hat{\eta})$ after "sleeping with all the suitors" (ouv-

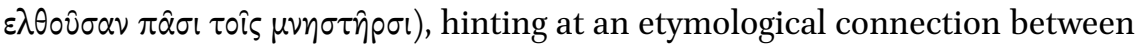
Pan's name ( $\Pi \alpha \dot{\nu})$ and her indiscriminate promiscuity (cf. $\pi \hat{\alpha} v$, "everything": $B N J \quad 76 \mathrm{~F} 21) .59$ Various other later testimonia also claim that she succumbed to the suitors' persistent advances: Pausanias records a Mantinean tradition in which Odysseus accused Penelope of infidelity and sent her away (8.12.56); Lycophron's Cassandra predicts that Penelope will "empty out" Odysseus's

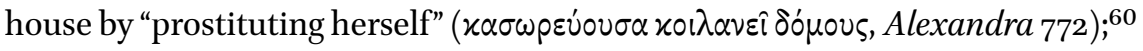
and the Epitome of Apollodorus's Bibliotheca refers to multiple traditions in which she was seduced by a specific suitor, including Amphinomus or Antinous (7.38-39). Moreover, already in the Telegony, Penelope marries Telegonus after he has killed his father, Odysseus, an uncomfortably Oedipal move (argumentum 4 b; fragment $6 \mathrm{GEF}){ }^{61}$

Of course, all of these accounts may be post-Homeric innovations, mischievous and counter-cultural reworkings of the Odyssey's image of a loyal and loving spouse. But it has also been argued that they reflect earlier pre-Homeric

$5^{8}$ See Haldane 1968: $23^{-25}$, who sifts the conflicting testimony regarding Pan's paternity (cf. Roscher 1894) and follows Timpanaro's argument that Pindar specified Hermes, not Apollo (1957:184-187 = 1978: 48o-486; cf. Snell 1964: 94). Later mentions of this Hermes tradition include Theocritus Palatine Anthology 15.21.1-2, 15; Cicero De natura deorum 3.22.56; Apollodorus Epitome 7.38; cf. too Mactoux 1975: 219-230.

59 See Okin 1980: 105-107; cf. too scholia on Theocritus Idyll 1.3/4c, 7.109/11ob-c; scholia on Oppian Halieutica 3.15; Servius Danielis on Vergil Aeneid 2.44; Pseudo-Nonnus, Commentaries 4.40. The same etymological connection is already evoked in the Homeric Hymn to

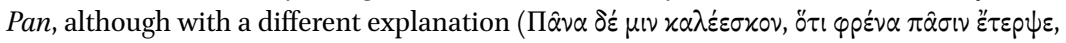
19.47).

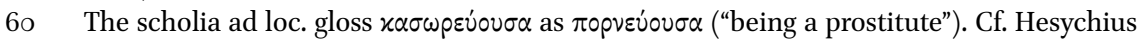

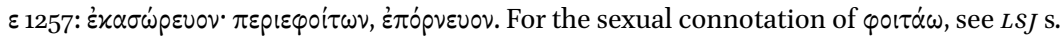
v. 3 .

61 For the Odyssey's possible awareness of and engagement with the Telegony tradition, see Tsagalis 2008: 63-9o; Arft 2019; Burgess 2019b. 
traditions which the Odyssey itself is at pains to "de-authorize," especially through the opening portrayal of Hermes as a critic of Aegisthus's adultery and a firm ally of Odysseus, negating his role as a potential rival for Penelope. ${ }^{62}$ Such a suggestion can be no more than an attractive possibility on available evidence, but if we entertain it as such, we may be able to discern further point in Homer's comparison of Penelope to the women of the Catalogue. Rather than simply signifying Penelope's pre-eminence, this insistent celebration of her excellence may also attempt to suppress alternative traditions in which she was no such paragon of virtue. If so, Homer does not tackle such problematic traditions head-on but rather skirts round them by positioning Penelope against the infidelity and sexual transgressions of other mythical women. The intertextual agōn that we have been tracing here may thus in fact be formed of two separate competitive moves: on the one hand, Homer explicitly marks Penelope's superiority to the women of the Catalogue; on the other hand, he may also implicitly silence and suppress uncomfortable Penelopean alternatives. Through these two complementary processes, the Odyssean Penelope's excellence would resound all the more definitively.

\section{Conclusions: The Agōn Expanded}

We have seen how the poet of the Odyssey agonistically positions his poem against a larger tradition of other songs, asserting the primacy of Penelope and-by extension-his own poem that celebrates her. This agonistic posturing is not an isolated moment but rather recurs at key points throughout the epic, reinforcing Penelope's superiority (and perhaps also pointedly suppressing alternative traditions of Penelopean infidelity). Over the course of the poem, the Ithacan queen almost becomes an embodiment of the Odyssey itself, as her intimate association with weaving and cunning aligns her closely with the poet's own production of song (cf. Clayton 2004; Hernández 2008).

To close, I would like to expand this analysis in two further directions: first, to suggest that this intertextual agōn is not solely limited to the character of Penelope in the Odyssey; and second, to chart one aspect of its Nachleben in later Greek culture.

First, this intertextual agōn extends beyond Penelope and the women of the Catalogue to embrace its male participants. The Odyssean suitors are strongly

62 Marks 2008: 25-30; cf. Fredricksmeyer 1997: 494-495. See too Matoux 1975: 225 on the various parallels between Odysseus and Hermes. 
associated with catalogic poetry themselves: they woo Penelope like Helen's suitors in the Catalogue (fragments 196-204 M-W) and are themselves frequently presented in list-form (Odyssey 16.245-253, 18.291-301, 22.241-243, 265268, 283-284: cf. Sammons 2010: 197-204). Like the heroines of myth, they too stand as representatives of catalogic tradition. Yet just as Tyro, Alcmene, and Mycene cannot compete with Penelope, so too do the suitors ultimately prove no match for Odysseus and his household by the end of the poem. Indeed, the suitors' inferiority may also be telegraphed earlier in the epic through their leader's less successful engagement with catalogue tradition. We have already noted Antinous's limited grasp of the implications of his catalogic reference in Odyssey 2, which is far less skillful than Telemachus's veiled and allusive back-reference in Odyssey 21. But even at a more basic level, his access to such traditions is inferior to Odysseus's own: Antinous relies on distant and

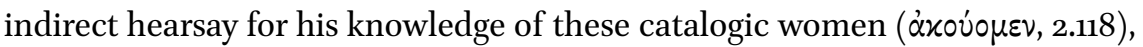
whereas Odysseus sees them and talks with them directly in the Nekyia. Indeed, the verb "iov ("I saw") repeatedly punctuates Odysseus's account, almost a direct replacement for catalogue poetry's repeated generic tag of $\ddot{\eta}$ oin (Odyssey 11.235, 26o, 266, 271, 321, 326, 329). Within epic poetry's broader prioritization of direct autopsy over indirect transmission (cf. Ford 1992: 57-67), Odysseus's eye-witness encounters set him above Antinous in his mastery of tradition. ${ }^{63}$ Odysseus outdoes the catalogic Antinous just as Penelope outshines the catalogic women. Both the men and the women of Odysseus's family ultimately surpass the emblematic representatives of the Catalogue of Women. Crucially, as we have seen, they are all united by their possession of $x \varepsilon \dot{p} \rho \delta \varepsilon \alpha$.

Secondly, we should note that this agonistic strategy had a long afterlife in antiquity, as fictional and real-life women continued to be compared with exemplars of the mythical past. In the post-Homeric tradition, however, Penelope transitioned from the tenor to the vehicle of such comparisons, acting as a recurring model of female excellence in a wide variety of genres. ${ }^{64}$ Richard Hunter has highlighted how Penelope "could function as a kind of shorthand for commemorating the merits of a dead wife" in sepulchral epigram, where she is repeatedly invoked as a paradigm and foil (2018: 7; cf. Peek 1965). So, for exam-

63 Odysseus's privileged knowledge also aligns him with epic poets, whose relationship with the Muses provides access to information beyond mere hearsay; see Bakker 2013: 8-10 for the connection between Odysseus's catalogue of heroines and the Iliad's catalogue of ships. Cf. esp. Iliad 2.485-486: the Muses' knowledge is derived from their physical presence $(\pi \dot{\alpha} \rho \varepsilon \sigma \tau \varepsilon)$, like Odysseus's in the Underworld; and without the Muses, "we only hear

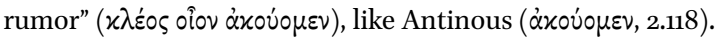

64 See, for example, Harrison 1988 on Horace Odes 3.7; Nelson 2020 on Theocritus Idyll 2. 
ple, a certain Severa from imperial Nicaea in Bithynia will prove "more sung

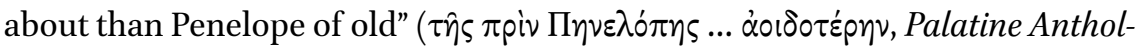
ogy 15.8.6 = o9/o5/o8 Merkelbach-Stauber), a claim that reworks Agamemnon's Underworld prediction of Penelope's promised fame (Odyssey 24.192-198) and asserts Penelope's priority $(\pi p i v)$, as Antinous did that of his female compara$n d a\left(\pi \alpha \lambda \alpha \iota \hat{\omega} v, \pi \alpha \dot{\alpha} \circ \varsigma_{5}, 2.118,119\right)$. To Hunter's examples, we should also add an imperial epigram from second-century CE Carales, modern-day Cagliari (6.5867 Cugusi $=2005.22-31$ Peek $)$ :

$$
\begin{aligned}
& \mu \eta x] \varepsilon \dot{\varepsilon} \tau\left[\iota \text { П } \eta \nu \varepsilon \lambda o^{\prime} \pi \eta \nu\right] \mu \eta \delta^{\prime} \mathrm{E}[\dot{\nu} \alpha] \delta \nu[\eta \nu \varkappa \varepsilon \lambda \alpha \delta \varepsilon i \tau \varepsilon \\
& \tau \dot{\eta}[\nu \pi 0 \tau \varepsilon \sigma \dot{\nu} \nu \mathrm{K} \alpha \pi \alpha] \nu \varepsilon \hat{\imath} \varphi[\lambda \circ \gamma] \mu \dot{\partial} \nu[\hat{\varepsilon} \sigma \alpha \lambda \alpha \mu \varepsilon \dot{\varepsilon} \nu \eta] \text {, }
\end{aligned}
$$

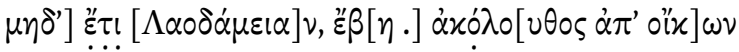

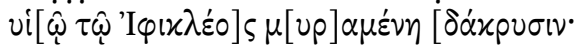

$$
\begin{aligned}
& \sigma i \gamma \alpha \dot{\alpha} \sigma \theta[\omega] \delta^{\prime}\left[{ }^{\prime \prime} A \lambda\right] \kappa \eta[\sigma \tau]\left\llcorner\varsigma, \dot{\varepsilon}^{\prime} \varphi^{\prime} \hat{\eta} \lambda i v \alpha \pi \rho 0[\ldots \ldots . . .] \alpha \nu\right.
\end{aligned}
$$

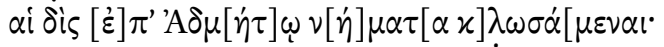

$$
\begin{aligned}
& \tau] \dot{\alpha} \varsigma \pi \circ[\lambda] v \theta \rho \nu \lambda[\dot{\eta} \tau 0] \nu[\varsigma] \dot{\eta} \rho \omega[i \delta \alpha] \varsigma, \dot{\alpha} \varsigma \delta \delta[\alpha \lambda \alpha i o \dot{s}
\end{aligned}
$$

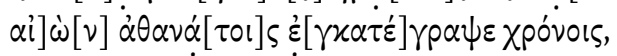

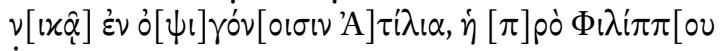

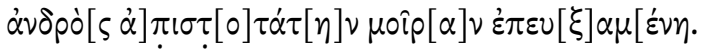

No longer sing of Penelope or Euadne, who once mounted the pyre ${ }^{65}$ alongside Capaneus, nor even of Laodameia, who accompanied the son of Iphiclus from their home, shedding tears. And let Alcestis's name lie silent, she for whom the Fates first unraveled(?) ${ }^{66}$ the threads of destiny, after they had spun them twice for Admetus. These much-celebrated heroines, whom ancient time ${ }^{67}$ has inscribed in eternity, Atilia surpasses among the late-born, she who prayed for a most unbelievable fate in place of her husband Philippus.

The author of this epigram asserts the superiority of Atilia Pomptilla over exemplary women of the mythical past, reworking Antinous's own Odyssean rhetoric. Not only does the poet list these women in catalogue form but he also describes them as "much-talked-of heroines" ( $\tau \dot{\alpha}] \varsigma \pi 0[\lambda] \nu \theta \rho \nu \lambda[\dot{\eta} \tau 0] \nu[\varsigma]$

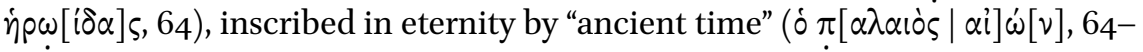

$65 \varphi[\lambda o \gamma] \mu$ óv evokes not only the flames of the thunderbolt by which Euadne died but also her flames of love (cf. LSJ s. v. 3 "metaph., heat of passion").

66 Translating Kaibel and Peek's $\pi \rho \hat{\omega}[\tau \circ \nu$ है $\lambda \nu \sigma] \alpha \nu$.

67 Or "long time," if we follow Magnelli 2007: $37-38$ in reading $\pi[\varepsilon p l \sigma \sigma o ́ \varsigma]$ at the end of verse 28 . 
65), expressions which mark their traditionality, just like Antinous's appeals to hearsay and antiquity. ${ }^{68}$ Given this larger echo of the Odyssey, it is perhaps no surprise that Penelope seems to have topped the list of comparanda. ${ }^{69}$ The Odyssey's competitive positioning of its female heroine proved a recurring pattern to elevate women of the present. But however pre-eminent Homer's Penelope may have been, she was eventually subsumed within a wider throng of past female exemplars.

\section{Appendix}

The women of the Odyssean and Hesiodic catalogues

\begin{tabular}{|c|c|c|c|}
\hline Name & Odyssey & Hesiod fragments & Other early epic sources \\
\hline 1. Tyro & $11.235^{-259}$ & $\begin{array}{l}30.24-42 \mathrm{M}-\mathrm{W}[27 \mathrm{M}, 20 \mathrm{H}] \\
31 \mathrm{M}-\mathrm{W}[30 \mathrm{M}, 24 \mathrm{H}] \\
3^{2} \mathrm{M}-\mathrm{W}[29 \mathrm{M}, 23 \mathrm{H}] \\
38 \mathrm{M}-\mathrm{W}[37 \mathrm{M}] \\
157 \mathrm{M}\end{array}$ & \\
\hline 2. Antiope & $11.260-265$ & $\begin{array}{l}181 \mathrm{M}-\mathrm{W}[124 \mathrm{M}, 87 \mathrm{H}] \\
182 \mathrm{M}-\mathrm{W}[125 \mathrm{M}] \\
183 \mathrm{M}-\mathrm{W}[126 \mathrm{M}]\end{array}$ & $\begin{array}{l}\text { Cypria argumentum } 4 \mathrm{~b} G E F \\
\text { Asius fragment } 1 G E F\end{array}$ \\
\hline 3. Alcmene & $11.266-268$ & $\begin{array}{l}\text { 193.19-2o M-W [136 M, 9o H] } \\
\left.\text { 195.8-63 M-W [138 M, 91 H = Scutum }{ }^{-}-56\right] \\
248 \mathrm{M}-\mathrm{W}[187 \mathrm{a} \text { M, Meg. Éh. } 10 \mathrm{H}] \\
249 \mathrm{M}-\mathrm{W}[187 \mathrm{~b} \text { M, Meg. Eh. } 11 \mathrm{H}]\end{array}$ & $\begin{array}{l}\text { Iliad } 14 \cdot 323,19.99,19.119 \\
\text { Theogony } 526,943,950 \\
\text { Scutum } 1-56,86-89,467 \\
\text { Homeric Hymn } 15 \cdot 3 \\
\text { Asius fragment } 4 \text { GEF }\end{array}$ \\
\hline 4. Megara & $11.269-270$ & ? & $\begin{array}{l}\text { Cypria argumentum } 4 \mathrm{~b} G E F \\
\text { Panyassis fragment } 1 G E F\end{array}$ \\
\hline 5. Epicaste & $11.271-280$ & $?^{70}$ & $\begin{array}{l}\text { Cypria argumentum } 4 \mathrm{~b} G E F \\
\text { Oedipodea fragment } 1 G E F\end{array}$ \\
\hline
\end{tabular}

68 For the verb $\theta p \cup \lambda \varepsilon \dot{\omega} \omega$ ("chatter") functioning as an "Alexandrian footnote," see O'Connell 2018: 254-256 on $\theta$ $0 \dot{\lambda} \eta \eta \theta \alpha$ in Sappho's Brothers Poem.

$69 \Pi \eta \nu \varepsilon \lambda \sigma^{\prime} \pi \nu$ is a supplement in the first verse but a very plausible one: another epigram from the same location describes Atilia Pomptilla as $\pi \varepsilon p i \varphi \rho \omega \nu$ (6.47 Cugusi), Penelope's archetypal epic epithet (Odyssey 1.329, 4.787, etc.): Coppola 1931: 413; Cugusi 2003: 138.

70 Oedipus's funeral is mentioned in the Catalogue (fragment $192 \mathrm{M}-\mathrm{W}[135 \mathrm{M}]$, fragment 193.4 M-W [136 M]), although he there seems to be the husband of Astymedusa (his third 
The women of the Odyssean and Hesiodic catalogues (cont.)

\begin{tabular}{|c|c|c|c|}
\hline Name & Odyssey & Hesiod fragments & Other early epic sources \\
\hline 6. Chloris & $11.281-297$ & $\begin{array}{l}33 \mathrm{a} .1-12 \mathrm{M}-\mathrm{W}[31 \mathrm{M}, 25 \mathrm{H}] \\
37.1-16 \mathrm{M}-\mathrm{W}[35 \mathrm{M}, 27 \mathrm{H}]\end{array}$ & \\
\hline 7. Leda & $11.298-304$ & $\begin{array}{l}23 \mathrm{a} \cdot 7-10 \mathrm{M}-\mathrm{W}[19 \mathrm{M}, 15 \mathrm{H}] \\
24 \mathrm{M}-\mathrm{W}[21 \mathrm{M}]\end{array}$ & $\begin{array}{l}\text { Cypria fragment } 11 \text { GEF } \\
\text { Homeric Hymn } 17 \cdot 3-4,33 \cdot 2 \\
\text { Eumelus fragment } 25 G E F \\
\text { Asius fragment } 6 G E F\end{array}$ \\
\hline 8. Iphimedeia & $11.305^{-320}$ & $\begin{array}{l}19 \mathrm{M}-\mathrm{W}[16 \mathrm{M}] \\
20 \mathrm{M}-\mathrm{W}[17 \mathrm{M}] \\
21 \mathrm{M}-\mathrm{W}[9 \mathrm{H}] \\
157 \mathrm{M}\end{array}$ & $\begin{array}{l}\text { [Iliad } 5 \cdot 3^{8} 5^{-}-391: \text { Otus and } \\
\text { Ephialtes] }\end{array}$ \\
\hline 9. Phaedra & 11.321 & $?^{71}$ & Theseis fragment 1 GEF \\
\hline 10. Procris & 11.321 & $332 \mathrm{M}-\mathrm{W}[282 \mathrm{M}]$ & \\
\hline 11. Ariadne & $11.3^{21}-325$ & $\begin{array}{l}147 \mathrm{M}-\mathrm{W}[243 \mathrm{M}] \\
298 \mathrm{M}-\mathrm{W}\left[235^{\mathrm{a}-\mathrm{b}} \mathrm{M}\right]\end{array}$ & $\begin{array}{l}\text { Iliad } 18.592 \\
\text { Theogony } 947-949 \\
\text { Cypria argumentum } 4 \text { b GEF }\end{array}$ \\
\hline 12. Maera & 11.326 & $?$ & Nostoi fragment ${ }_{5} G E F$ \\
\hline 13. Clymene & 11.326 & $\begin{array}{l}62 \mathrm{M}-\mathrm{W}[61 \mathrm{M}] \\
\text { 261a M }\end{array}$ & Nostoi fragment $4 G E F$ \\
\hline 14. Eriphyle & $11.3^{26}-3^{27}$ & $?$ & $\begin{array}{l}\text { Thebaid fragment } 7 G E F \\
\text { Asius fragment } 4 G E F\end{array}$ \\
\hline
\end{tabular}

\section{Acknowledgments}

Earlier versions of this piece were presented at the CA/FIEC 2019 conference in London and at a seminar in Cambridge in 2021. I would like to thank the audience members on both occasions for their many helpful suggestions, especially

wife: cf. Pherecydes fragment 95 EGM; West 1985: 110-111; Fowler 2013: 402-408); for his funeral, cf. too Iliad 23.679-680.

71 According to Athenaeus, "Hesiod" mentioned a number of Theseus's wives (fragment 147 M-W [243 M]); Athenaeus does not name Phaedra explicitly, but West 1985: 108 suspects that she might have featured. 
Emma Greensmith, Sophus Helle, Richard Janko, Martina Astrid Rodda, and Selena Wisnom. I am also grateful to those who offered generous feedback and suggestions on written drafts: Richard Hunter, Matthew Ward, Alan Woolley, and the editors and anonymous readers of YAGE.

\section{Works Cited}

BNJ Worthington, I. ed. 2007-. Brill's New Jacoby. Online: http://referenceworks .brillonline.com/browse/brill-s-new-jacoby.

EGM Fowler, R.L. 2000-2013. Early Greek Mythography. 2 vols. Oxford: Oxford University Press.

GEF West, M.L. 2003 Greek Epic Fragments: From the Seventh to the Fifth Centuries BC. Cambridge, MA: Harvard University Press.

H Hirschberger, M. 2004. Gynaikōn Katalogos und Megalai Ēhoiai:Ein Kommentar zu den Fragmenten zweier hesiodeischer Epen. Munich: K.G. Saur.

M Most, G.W. 2018. Hesiod. 2 vols. Cambridge, MA: Harvard University Press.

M-W Merkelbach, R. and West, M. 1967. Fragmenta Hesiodea. Oxford: Clarendon Press.

Alden, M.J. 2017. Para-Narratives in the Odyssey: Stories in the Frame. Oxford: Oxford University Press.

Allan, W. and Cairns, D.L. 2011. "Conflict and Community in the Iliad." In Fisher, N. and van Wees, H. eds. Competition in the Ancient World. Swansea: Classical Press of Wales. $113-146$.

Alwine, A.T. 2009. "The Non-Homeric Cyclops in the Homeric Odyssey." Greek, Roman, and Byzantine Studies 49: 323-333.

Andersen, Ø. and Haug, D.T.T. eds. 2012. Relative Chronology in Early Greek Epic Poetry. Cambridge: Cambridge University Press.

Arft, J. 2019. "Agnoēsis and the Death of Odysseus in the Odyssey and the Telegony." Yearbook of Ancient Greek Epic 3: 158-179.

Arrighetti, G. 1996. "Hésiode et les Muses: Le don de la vérité et la conquête de la parole." In Blaise, F., Judet de La Combe, P., and Rousseau, P. eds. Le Métier du mythe:Lectures d'Hésiode. Villeneuve d'Ascq: Presses universitaires du Septentrion. 53-70.

Bakker, E.J. 2013. The Meaning of Meat and the Structure of the Odyssey. New York: Cambridge University Press.

Barker, E.T.E. 2009. Entering the Agon: Dissent and Authority in Homer, Historiography and Tragedy. Oxford: Oxford University Press.

Barker, E.T.E. and Christensen, J.P. 2015. “Odysseus's Nostos and the Odyssey's Nostoi: Rivalry within the Epic Cycle." Philologia antiqua 7: 85-110. 
Barker, E.T.E. and Christensen, J.P. 2020. Homer's Thebes: Epic Rivalries and the Appropriation of Mythical Pasts. Washington, DC: Center for Hellenic Studies.

Bassino, P. 2019. The Certamen Homeri et Hesiodi: A Commentary. Berlin: Walter de Gruyter.

Bassino, P., Canevaro, L.G., and Graziosi, B. eds. 2017. Conflict and Consensus in Early Hexameter Poetry. Cambridge: Cambridge University Press.

Brillante, C. 1992 "Le Muse di Thamyris." Studi classici e orientali 41: 429-453.

Büchner, W. 1937. "Probleme der Homerischen Nekyia." Hermes 72: 104-122.

Burgess, J.S. 2001. The Tradition of the Trojan War in Homer and the Epic Cycle. Baltimore: Johns Hopkins University Press.

Burgess, J.S. 20o6. "Neoanalysis, Orality, and Intertextuality: An Examination of Homeric Motif Transference." Oral Tradition 21: 148-189.

Burgess, J.S. 2009. The Death and Afterlife of Achilles. Baltimore: Johns Hopkins University Press.

Burgess, J.S. 2012. "Intertextuality without Text in Early Greek Epic." In Andersen and Haug, eds. 168-183.

Burgess, J.S. 2017. “The Apologos of Odysseus: Tradition and Conspiracy Theories.” In Tsagalis and Markantonatos, eds. 95-120.

Burgess, J.S. 2019a. "Introduction." Yearbook of Ancient Greek Epic 3: 1-47.

Burgess, J.S. 2019b. “The Corpse of Odysseus." Yearbook of Ancient Greek Epic 3: 136-157.

Christensen, J.P. 2018. "Eris and Epos: Composition, Competition, and the Domestication of Strife." Yearbook of Ancient Greek Epic 2: 1-39.

Cingano, E. 199o. "Lo strano ingresso di Aiace nel Catalogo delle donne esiodeo." In Schachter, A. ed. Essays in the Topography, History and Culture of Boiotia. Montreal: Department of Classics, McGill University. 111-117.

Cingano, E. 2005. "A Catalogue within a Catalogue: Helen's Suitors in the Hesiodic Catalogue of Women (frr. 196-204)." In Hunter, ed. 118-152.

Clayton, B. 2004. A Penelopean Poetics: Reweaving the Feminine in Homer's Odyssey. Lanham, MD: Lexington Books.

Cohen, B. ed. 1995. The Distaff Side: Representing the Female in Homer's Odyssey. New York: Oxford University Press.

Collins, D. 2004. Master of the Game: Competition and Performance in Greek Poetry. Washington, DC: Center for Hellenic Studies.

Cook, E.F. 1995. The Odyssey in Athens: Myths of Cultural Origins. Ithaca, NY: Cornell University Press.

Coppola, G. 1931. "L'Heroon di Atilia Pomptilla in Cagliari." Rendiconti della Reale Accademia nazionale dei Lincei: Classe di scienze morali, storiche e filologiche, serie sesta, 7:388-437.

Cugusi, P. 2003. Carmina latina epigraphica provinciae Sardiniae: Introduzione, testo critico, commento e indici. Bologna: Pàtron Editore. 
Currie, B. 2016. Homer's Allusive Art. Oxford: Oxford University Press.

D’Alessio, G.B. 2005. "The Megalai Ehoiai: A Survey of the Fragments." In Hunter, ed. 176-216.

Damon, C. and Pieper, C. eds. 2019. Eris vs. Aemulatio: Valuing Competition in Classical Antiquity. Leiden: Brill.

Danek, G. 1998. Epos und Zitat: Studien zu den Quellen der Odyssee. Vienna: Österreichische Akademie der Wissenschaften.

D’Arms, E.F. and Hulley, K.K. 1946. "The Oresteia-story in the Odyssey." Transactions and Proceedings of the American Philological Association 77: 207-213.

Davies, M. 1991. Poetarum melicorum graecorum fragmenta. Oxford: Clarendon Press.

Deremetz, A. 2005. "L'Histoire du genre épique dans les catabases de Virgile, d'Ovide et de Silius Italicus." In Schwindt, J.P. ed. La représentation du temps dans la poésie augustéenne. Heidelberg: Universitätsverlag Winter. 111-121.

Doherty, L.E. 1991. "The Internal and Implied Audiences of Odyssey11." Arethusa 24:145176.

Doherty, L.E. 1992. "Gender and Internal Audiences in the Odyssey." American Journal of Philology 113: 161-177. Reprinted in Doherty 2009: 247-264.

Doherty, L.E. 1995. Siren Songs: Gender, Audiences, and Narrators in the Odyssey. Ann Arbor: University of Michigan Press.

Doherty, L.E. 2008. "Nausikaa and Tyro: Idylls of Courtship in the Phaiakian Episode of the Odyssey and the Hesiodic Catalogue of Women." Phoenix 62: 63-76.

Doherty, L.E. ed. 2009. Oxford Readings in Classical Studies: Homer's Odyssey. Oxford: Oxford University Press.

Dougherty, C. 2001. The Raft of Odysseus: The Ethnographic Imagination of Homer's Odyssey. New York: Oxford University Press.

Edmunds, L. 2016. "Intertextuality without Texts in Archaic Greek Verse and the Plan of Zeus." Syllecta classica 27:1-27.

Edwards, A.T. 1985. Achilles in the Odyssey: Ideologies of Heroism in the Homeric Epic. Königstein/Ts.: Anton Hain.

Epstein, K. 2020. "A Poetics of Competition in Conjugal Bedroom Conversation in the Iliad, the Odyssey, and the Argonautica." Hermes 148: 128-148.

Erbse, H. 1972. Beiträge zum Verständnis der Odyssee. Berlin: Walter de Gruyter.

Felson, N. 1994. Regarding Penelope: From Character to Poetics. Princeton: Princeton University Press.

Fernández-Galiano, M. 1992 “Books XxI-XXII." In Russo, J., Fernández-Galiano, M., and Heubeck, A. eds. A Commentary on Homer's Odyssey. Volume III: Books XVII-XXIV. Oxford: Clarendon Press. 129-310.

Finkelberg, M. 1988. “Ajax's Entry in the Hesiodic Catalogue of Women.” Classical Quarterly 38: 31-41. Reprinted in Finkelberg 2020: 291-304.

Finkelberg, M. 1998. The Birth of Literary Fiction in Ancient Greece. Oxford: Clarendon Press. 
Finkelberg, M. 2003 “Homer as a Foundation Text." In Finkelberg, M. and Stroumsa, G.G. eds. Homer, the Bible, and Beyond: Homer, the Bible, and Beyond: Literary and Religious Canons in the Ancient World. Leiden: Brill. 75-96. Reprinted in Finkelberg 2020: 318-33o.

Finkelberg, M. 2011. "Homer and His Peers: Neoanalysis, Oral Theory, and the Status of Homer." Trends in Classics 3: 197-208. Reprinted in Finkelberg 2020: 158-168.

Finkelberg, M. 2015. "Meta-Cyclic Epic and Homeric Poetry." In Fantuzzi, M. and Tsagalis, C.C. eds. The Greek Epic Cycle and its Ancient Reception: A Companion. Cambridge: Cambridge University Press. 126-138. Reprinted in Finkelberg 2020: 169-181. Finkelberg, M. 2018. "The Formation of the Homeric Epics." In Mutschler, F.-H. ed. Singing the World. The Homeric Epics and the Chinese Book of Songs: Foundational Texts Compared. Newcastle Upon Tyne: Cambridge Scholars Publishing. 15-38. Reprinted in Finkelberg 2020: 182-196.

Finkelberg, M. 2020. Homer and Early Greek Epic: Collected Essays. Berlin: Walter de Gruyter.

Foley, H.P. 1978. “'Reverse Similes' and Sex Roles in the Odyssey." Arethusa 11: 7-26. Reprinted in Doherty 2009: 189-207.

Foley, H.P. 1995. "Penelope as Moral Agent." In Cohen, ed. 93-115.

Ford, A.L. 1992. Homer: The Poetry of the Past. Ithaca, NY: Cornell University Press.

Ford, A.L. 2002. The Origins of Criticism: Literary Culture and Poetic Theory in Classical Greece. Princeton: Princeton University Press.

Fowler, R.L. 2013 Early Greek Mythography. Volume 2: Commentary. Oxford: Oxford University Press.

Fredricksmeyer, H.C. 1997. "Penelope Polutropos: The Crux at Odyssey 23.218-224." American Journal of Philology 118: 487-497.

Gazis, G.A. 2018. Homer and the Poetics of Hades. Oxford: Oxford University Press.

Gostoli, A., Fongoni, A., and Biondi, F. eds. 2017. Poeti in agone: Competizioni poetiche e musicali nella Grecia antica. Turnhout: Brepols Publishers.

Graziosi, B. 2001. "Competition in Wisdom." In Budelmann, F. and Michelakis, P. eds. Homer, Tragedy and Beyond: Essays in Honour of P.E. Easterling. London: Society for the Promotion of Hellenic Studies. 57-74.

Graziosi, B. 2002. Inventing Homer: The Early Reception of Epic. Cambridge: Cambridge University Press.

Grethlein, J. 2017. "The Best of the Achaeans? Odysseus and Achilles in the Odyssey." In Tsagalis and Markantonatos, eds. 121-142.

Grethlein, J. and Rengakos, A. eds. 20o9. Narratology and Interpretation: The Content of Narrative Form in Ancient Literature. Berlin: Walter de Gruyter.

Griffith, M. 199o. "Contest and Contradiction in Early Greek Poetry." In Griffith, M. and Mastronarde, D.J. eds. Cabinet of the Muses: Essays on Classical and Comparative Literature in honor of Thomas G. Rosenmeyer. Atlanta: Scholars Press. 185-207. 
Haldane, J.A. 1968. "Pindar and Pan: frs. 95-100 Snell." Phoenix 22: 18-31.

Hardie, P.R. 2004. "In the Steps of the Sibyl: Tradition and Desire in the Epic Underworld." Materiali e discussioni per l'analisi dei testi classici 52: 143-156.

Harrison, S.J. 1988. “Horace, Odes 3.7: An Erotic Odyssey?” Classical Quarterly 38: 186192.

Hernández, P.N. 2008. "Penelope's Absent Song." Phoenix 62: 39-62.

Heubeck, A. 1954. Der Odyssee-Dichter und die Ilias. Erlangen: Palm \& Enke.

Hinds, S. 1998. Allusion and Intertext: Dynamics of Appropriation in Roman Poetry. Cambridge: Cambridge University Press.

Hirschberger, M. 2001. "Die Erzählungen der Frauen in der Nekyia der Odyssee." In Païsi-Apostolopoulou, M. ed. Eranos: Proceedings of the Ninth International Symposium on the Odyssey, 2-7 September 2000. Ithaca: Centre for Odyssean Studies. 123-151.

Hirschberger, M. 2004. Gynaikōn Katalogos und Megalai Ēhoiai: Ein Kommentar zu den Fragmenten zweier hesiodeischer Epen. Munich: K.G. Saur.

Hölscher, U. 1967. "Die Atridensage in der Odyssee." In Singer, H. and von Wiese, B. eds. Festschrift für Richard Alewyn. Cologne: Böhlau. 1-16.

Houlihan, J. 1994. "Incorporating the Other: The Catalogue of Women in Odyssey 11." Electronic Antiquity: Communicating the Classics 2.1. https://scholar.lib.vt.edu/ejour nals/ElAnt/V2N1/houlihan.html.

Hunter, R.L. ed. 2005. The Hesiodic Catalogue of Women: Constructions and Reconstructions. Cambridge: Cambridge University Press.

Hunter, R.L. 2018. The Measure of Homer: The Ancient Reception of the Iliad and the Odyssey. Cambridge: Cambridge University Press.

de Jong, I.J.F. 2001. A Narratological Commentary on the Odyssey. Cambridge: Cambridge University Press.

Kambylis, A. 1965. Die Dichterweihe und ihre Symbolik: Untersuchungen zu Hesiodos, Kallimachos, Properz und Ennius. Heidelberg: Carl Winter.

Kanavou, N. 2015. The Names of Homeric Heroes: Problems and Interpretations. Berlin: Walter de Gruyter.

Kassel, R. and Austin, C. 1983-2001. Poetae comici graeci. 8 vols. Berlin: Walter de Gruyter.

Katz, M.A. 1991. Penelope's Renown: Meaning and Indeterminacy in the Odyssey. Princeton: Princeton University Press.

Kelly, A. 2007. "How to End an Orally-Derived Epic Poem." Transactions of the American Philological Association 137: 371-402.

Kelly, A. 2008. "Performance and Rivalry: Homer, Odysseus and Hesiod." In Revermann, M. and Wilson, P. eds. Performance, Iconography, Reception: Studies in Honour of Oliver Taplin. Oxford: Oxford University Press. 177-203.

Kelly, A. 2018. "Homer's Rivals? Internal Narrators in the Iliad." In Ready and Tsagalis, eds. $351-377$. 
King, B. 1999. "The Rhetoric of the Victim: Odysseus in the Swineherd's Hut." Classical Antiquity 18: 74-93.

Larson, S. 2014. "Boeotia, Athens, the Peisistratids, and the Odyssey's Catalogue of Heroines.” In Tsagalis, ed. 412-427.

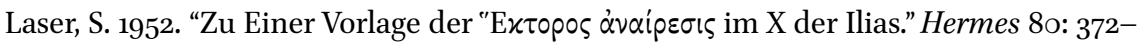
376.

Lesser, R.H. 2017. “The Pandareids and Pandora: Defining Penelope's Subjectivity in the Odyssey." Helios 44: 101-132.

Lesser, R.H. 2019. "Female Ethics and Epic Rivalry: Helen in the Iliad and Penelope in the Odyssey." American Journal of Philology 140: 189-226.

Mactoux, M.M. 1975. Pénélope: Légende et mythe. Paris: Belles Lettres.

Maehler, H. 1963. Die Auffassung des Dichterberufs im frühen Griechentum bis zur Zeit Pindars. Göttingen: Vandenhoeck \& Ruprecht.

Magnelli, E. 2007. "Notes on Four Greek Verse Inscriptions." Zeitschrift für Papyrologie und Epigraphik 16o: 37-40.

Marks, J. 2003. "Alternative Odysseys: The Case of Thoas and Odysseus." Transactions of the American Philological Association 133: 209-226.

Marks, J. 2008. Zeus in the Odyssey. Washington, DC: Center for Hellenic Studies.

Marks, J. 2017. "Conflict and Consensus in the Epic Cycle." In Bassino, Canevaro and Graziosi, eds. 154-169.

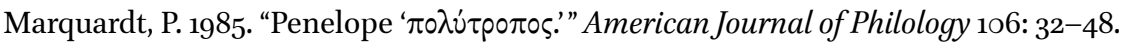

Martin, R.P. 1989. The Language of Heroes: Speech and Performance in the Iliad. Ithaca, NY: Cornell University Press.

Martin, R.P. 2015. "Festivals, Symposia, and the Performance of Greek Poetry." In Destrée, P. and Murray, P. eds. A Companion to Ancient Aesthetics. Chichester: Wiley Blackwell. 17-30.

Merkelbach, R. and Stauber, J. 2001. Steinepigramme aus dem griechischen Osten. Band 2: Die Nordküste Kleinasiens (Marmarameer und Pontos). Munich: K.G. Saur.

Most, G.W. 1992. "Il poeta nell'Ade: Catabasi epica e teoria dell'epos tra Omero e Virgilio." Studi italiani di filologia classica 10: 1014-1026.

Moulton, C. 1974. "The End of the Odyssey." Greek, Roman, and Byzantine Studies 15:153169.

Murnaghan, S. 1986. "Penelope's Agnoia: Knowledge, Power, and Gender in the Odyssey." In Skinner, M. ed. Rescuing Creusa. New Methodological Approaches to Women in Antiquity. Helios 13.2: 103-115. Reprinted in Doherty 20o9: 231-246.

Nagy, G. 1974. Comparative Studies in Greek and Indic Meter. Cambridge, MA: Harvard University Press.

Nagy, G. 1979. The Best of the Achaeans: Concepts of the Hero in Archaic Greek Poetry. Baltimore: Johns Hopkins University Press.

Nagy, G. 1982. "Hesiod." In Luce, T.J. ed. Ancient Writers: Greece and Rome. Volume I: Homer to Caesar. New York: Charles Scribner's Sons. 43-73 
Nagy, G. 199o. Greek Mythology and Poetics. Ithaca, NY: Cornell University Press.

Nasta, M. 2006. "La typologie des catalogues d'Éhées: Un réseau généalogique thématisé." Kernos 19: 59-78.

Nelson, T.J. 2020. "Penelopean Simaetha: A Flawed Paradigm of Femininity in Theocritus' Second Idyll." In Cusset, C., Belenfant, P. and Nardone, C.-E. eds. Féminités hellénistiques: Voix, genre, représentations. Leuven: Peeters. 387-405.

Nelson, T.J. Forthcoming a. Markers of Allusion in Archaic Greek Poetry. Cambridge: Cambridge University Press.

Nelson, T.J. Forthcoming b. "Talk and Text: The Pre-Alexandrian Footnote from Homer to Theodectes." In Kelly, A. and Spelman, H.L. eds. Texts and Intertexts in Archaic and Classical Greece. Cambridge: Cambridge University Press.

Northrup, M.D. 1980. “Homer's Catalogue of Women.” Ramus 9:150-159.

O'Connell, P.A. 2018. "'Charaxus Arrived with a Full Ship!' The Poetics of Welcome in Sappho's Brothers Song and the Charaxus Song Cycle." Classical Antiquity 37: 236266.

Okin, L.A. 1980. "A Hellenistic Historian Looks at Mythology: Duris of Samos and the Mythical Tradition." In Burstein, S.M. and Okin, L.A. eds. Panhellenica: Essays in Ancient History and Historiography in Honor of Truesdell S. Brown. Lawrence, KS: Coronado Press. 97-118.

Olson, S.D. 199o. "The Stories of Agamemnon in Homer's Odyssey." Transactions of the American Philological Association 120: 57-71.

Olson, S.D. 1995. Blood and Iron: Stories and Storytelling in Homer's Odyssey. Leiden: Brill.

Ormand, K. 2014. The Hesiodic Catalogue of Women and Archaic Greece. New York: Cambridge University Press.

Pade, M. 1983. "Homer's Catalogue of Women." Classica et mediaevalia 34: 7-15.

Parkes, R. 2010. "Dealing with Ghosts: Literary Assertion in Statius' Thebaid." Ramus 39: 14-23.

Peabody, B. 1975. The Winged Word: A Study in the Technique of Ancient Greek Oral Composition as Seen Principally Through Hesiod's Works and Days. Albany: State University of New York Press.

Peek, W. 1955. Griechische Vers-Inschriften. Band 1: Grab-Epigramme. Berlin: AkademieVerlag.

Peek, W. 1965. "Die Penelope der Ionerinnen." Mitteilungen des Deutschen Archäologischen Instituts, Athenische Abteilung 80:16o-169.

Peradotto, J. 199o. Man in the Middle Voice: Name and Narration in the Odyssey. Princeton: Princeton University Press.

Pfeiffer, R. 1949-1953. Callimachus. 2 vols. Oxford: Clarendon Press.

Pucci, P. 1987. Odysseus Polutropos: Intertextual Readings in the Odyssey and the Iliad. Ithaca, NY: Cornell University Press. 
Puelma, M. 1989. "Der Dichter und die Wahrheit in der griechischen Poetik von Homer bis Aristoteles." Museum Helveticum 46: 65-100.

Rawles, R. 2018. Simonides the Poet: Intertextuality and Reception. Cambridge: Cambridge University Press.

Ready, J.L. 2019. Orality, Textuality, and the Homeric Epics: An Interdisciplinary Study of Oral Texts, Dictated Texts, and Wild Texts. Oxford: Oxford University Press.

Ready, J.L. and Tsagalis, C.C. eds. 2018. Homer in Performance: Rhapsodes, Narrators, and Characters. Austin: University of Texas Press.

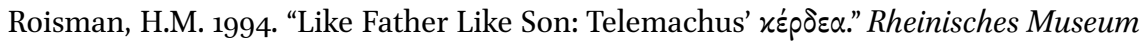
für Philologie 137: 1-22.

Roscher, W.H. 1894. "Die Sagen von der Geburt des Pan." Philologus 53: 362-377.

Rosen, R.M. 199o. "Poetry and Sailing in Hesiod's Works and Days." Classical Antiquity 9: 99-113.

Rotstein, A. 2012. "Mousikoi Agones and the Conceptualization of Genre in Ancient Greece." Classical Antiquity 31: 92-127.

Rutherford, I.C. 200o. "Formulas, Voice, and Death in Ehoie-Poetry, the Hesiodic Gunaikon Katalogos, and the Odysseian Nekuia." In Depew, M. and Obbink, D. eds. Matrices of Genre:Authors, Canons, and Society. Cambridge, MA: Harvard University Press. $81-96$.

Rutherford, I.C. 2012. "The Catalogue of Women within the Greek Epic Tradition: Allusion, Intertextuality and Traditional Referentiality." In Andersen and Haug, eds. 152167.

Rutherford, I.C. ed. 2019. Oxford Readings in Classical Studies: Greek Lyric. Oxford: Oxford University Press.

Sammons, B. 2010. The Art and Rhetoric of the Homeric Catalogue. New York: Oxford University Press.

Sammons, B. 2014. "A Tale of Tydeus: Exemplarity and Structure in Two Homeric Insets." In Tsagalis, ed. $297-318$.

Sammons, B. 2019. "The Space of the Epigone in Early Greek Epic." Yearbook of Ancient Greek Epic 3: 48-66.

Scodel, R.S. 2001. "Poetic Authority and Oral Tradition in Hesiod and Pindar." In Watson, J. ed. Speaking Volumes: Orality and Literacy in the Greek and Roman World. Leiden: Brill. 109-137.

Scodel, R.S. 2002. Listening to Homer: Tradition, Narrative, and Audience. Ann Arbor: University of Michigan Press.

Scodel, R.S. 2004. “The Modesty of Homer." In MacKie, C.J. ed. Oral Performance and its Context. Leiden: Brill. 1-19.

Scodel, R.S. 2008. Epic Facework: Self-Presentation and Social Interaction in Homer. Swansea: Classical Press of Wales.

Scodel, R.S. 2012. "Hesiod and the Epic Cycle." In Montanari, F., Rengakos, A., and Tsa- 
galis, C.C. eds. Homeric Contexts: Neoanalysis and the Interpretation of Oral Poetry. Berlin: Walter de Gruyter. 501-515.

Skempis, M. and Ziogas, I. 20og. "Arete's Words: Etymology, Ehoie-Poetry and Gendered Narrative in the Odyssey." In Grethlein and Rengakos, eds. 213-240.

Snell, B. 1964. Pindari carmina cum fragmentis. 3 rd ed. Pars altera: fragmenta, indices. Leipzig: Teubner.

Snell, B. and Maehler, H. 1987-1989. Pindari carmina cum fragmentis. 8th ed. 2 vols. Leipzig: Teubner.

Spelman, H.L. 2018a. "Event and Artefact: The Hymn to Apollo, Archaic Lyric, and Early Greek Literary History." In Budelmann, F. and Phillips, T. eds. Textual Events: Performance and the Lyric in Early Greece. Oxford: Oxford University Press. 151-171.

Spelman, H.L. 2018b. Pindar and the Poetics of Permanence. Oxford: Oxford University Press.

Stanford, W.B. 1959. The Odyssey of Homer. Edited with General and Grammatical Introduction, Commentary and Indexes. Volume I:Books I-XII. 2nd ed. London:Macmillan.

Steiner, D.T. 2005. "Nautical Matters: Hesiod's Nautilia and Ibycus Fragment 282 PMG." Classical Philology 100: 347-355. Reprinted in Rutherford 2019: 368-379.

Steiner, D.T. 2007. "Feathers Flying: Avian Poetics in Hesiod, Pindar, and Callimachus." American Journal of Philology 128: 177-208.

Steinrück, M. 1994. "Die fremde Stimme: Der Erzähler und das Schweigen der Frauen im 11. Buch der Odyssee." Kleos 1: 83-128.

Tarrant, R.J. 2012. Virgil: Aeneid Book XII. Cambridge: Cambridge University Press.

Thalmann, W.G. 1984. Conventions of Form and Thought in Early Greek Epic Poetry. Baltimore: Johns Hopkins University Press.

Timpanaro, S. 1957. "Note Serviane, con contributi ad altri autori e a questioni di lessicografia latina." Studi urbinati, serie B-Scienze umane e sociali 31: 155-198. Reprinted in Timpanaro 1978: 427-508.

Timpanaro, S. 1978. Contributi di filologia e di storia della lingua latina. Rome: Edizioni dell'Ateneo \& Bizzarri.

Tsagalis, C.C. 2008. The Oral Palimpsest: Exploring Intertextuality in the Homeric Epics. Washington, DC: Center for Hellenic Studies.

Tsagalis, C.C. 20og. "Poetry and Poetics in the Hesiodic Corpus." In Montanari, F., Rengakos, A., and Tsagalis, C.C. eds. Brill's Companion to Hesiod. Leiden: Brill. 131-177.

Tsagalis, C.C. 2011a. "Intertextuality." In Finkelberg, M. ed. The Homer Encyclopedia. Oxford: Wiley-Blackwell. 413-414.

Tsagalis, C.C. 2011b. "Towards an Oral, Intertextual Neoanalysis." Trends in Classics 3: 209-244.

Tsagalis, C.C. ed. 2014a. Theban Resonances in Homeric Epic. Berlin: Walter de Gruyter.

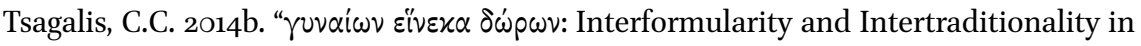
Theban and Homeric Epic." In Tsagalis, ed. 357-398. 
Tsagalis, C.C. 2018. "Performance Contexts for Rhapsodic Recitals in the Archaic and Classical Periods." In Ready and Tsagalis, eds. 29-75.

Tsagalis, C.C. and Markantonatos, A. eds. 2017. The Winnowing Oar-New Perspectives in Homeric Studies: Studies in Honor of Antonios Rengakos. Berlin: Walter de Gruyter.

Tsagarakis, O. 2000. Studies in Odyssey 11. Stuttgart: Franz Steiner.

Tsitsibakou-Vasalos, E. 20o9. "Chance or Design? Language and Plot Management in

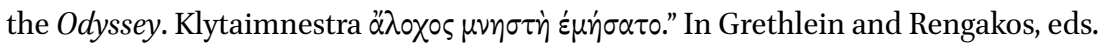
177-212.

Walcot, P. 1959. "The Theme of Unhappy Love in the Odyssey." Euphrosyne 2: 173-179.

van Wees, H. 1992. Status Warriors: War, Violence and Society in Homer and History. Amsterdam: J.C. Gieben.

Wender, D. 1978. The Last Scenes of the Odyssey. Leiden: Brill.

West, M.L. 1985. The Hesiodic Catalogue of Women: Its Nature, Structure, and Origins. Oxford: Clarendon Press.

West, M.L. 2004. "An Indo-European Stylistic Feature in Homer." In Bierl, A., Schmitt, A. and Willi, A. eds. Antike Literatur in neuer Deutung: Festschrift für Joachim Latacz anlässlich seines 70. Geburtstages. Munich: K.G. Saur. 33-49.

West, M.L. 2007. Indo-European Poetry and Myth. Oxford: Oxford University Press.

West, S.R. 1988. "Books I-IV." In Heubeck, A., West, S.R., and Hainsworth, J.B. eds. A Commentary on Homer's Odyssey. Volume I: Introduction and Books I-VIII. Oxford: Clarendon Press. 49-245.

West, S.R. 2012. "Odyssean Stratigraphy." In Andersen and Haug, eds. 122-137.

Wills, J. 1996. Repetition in Latin Poetry: Figures of Allusion. Oxford: Clarendon Press.

Wilson, D.F. 2005. "Demodokos' Iliad and Homer's." In Rabel, R.J. ed. Approaches to Homer, Ancient \& Modern. Swansea: Classical Press of Wales. 1-20.

Wilson, P. 20o6. "Thamyris of Thrace and the Muses of Messenia." Mediterranean Archaeology 19/20: 207-212.

Winkler, J.J. 1990. The Constraints of Desire: The Anthropology of Sex and Gender in Ancient Greece. London: Routledge.

Wyatt, W.F. 1989. "The Intermezzo of Odyssey 11 and the Poets Homer and Odysseus." Studi micenei ed egeo-anatolici 27: 235-253.

Zeitlin, F.I. 1995. "Figuring Fidelity in Homer's Odyssey." In Cohen, ed. 117-152.

Ziogas, I. 2013. Ovid and Hesiod: The Metamorphosis of The Catalogue of Women. Cambridge: Cambridge University Press.

Zutt, G. 1894. Über den Katalog der Heroinen in der Nekyia. Leipzig: Teubner. 